\title{
Electoral Management of Digital Campaigns and Disinformation in East and Southeast Asia
}

\author{
Netina Tan
}

\begin{abstract}
Election interference is a problem in digitized elections around the world. Given East and Southeast Asia's dense social network, electoral integrity is a growing concern. Yet, few studies focus on this region's regulatory approaches to data-driven campaigns or disinformation threat. This article addresses this by proposing an electoral management digital readiness (EMDR) index to compare the readiness of the ten electoral management bodies (EMBs) in East and Southeast Asia to respond to digital disruptions. The aim is to take stock of the new and amended laws and provide a composite index based on four key criteria, namely, the (1) type of electoral management model; (2) presence of specific or new regulations governing online campaign and disinformation; (3) confidence in the rule of law; and (4) technological readiness of the digital economy. Based on available legal statutes and cross-country indicators, this study finds the EMBs in Singapore, South Korea, Japan, Taiwan, and Thailand to have a high level of digital readiness; Malaysia, the Philippines, and Indonesia to have a medium level; and Cambodia and Myanmar to have a low level. A key finding is that a multi-pronged regulatory approach that involves different stakeholders is necessary to improve the timeliness of fact-checking and removal of malicious content, rather than relying on state-led initiatives to improve online electoral governance.
\end{abstract}

Keywords: electoral management bodies, social media, regulatory framework, online readiness index, disinformation, political communication, East and Southeast Asia

\section{INTRODUCTION}

$\mathbf{S}$ OCIAL MEDIA NETWORKS such as Facebook, Twitter, and YouTube have changed political communication and campaigns since Barack Obama's presidential campaign in 2008. Since then, election management bodies (EMBs), political parties, and candidates around the world have been using the

Netina Tan, $\mathrm{PhD}$, is an associate professor in the Department of Political Science at McMaster University in Hamilton, Ontario, Canada. Dr. Tan acknowledges the support of Social Sciences and Humanities Research Council for the research and writing of this article. She is grateful to the editor, three anonymous reviewers, Tony Porter, and Cassandra Preece for their insightful comments on an earlier version of this manuscript, and also indebted to Elaina Nguyen, Eric Lim, and Cassidy Bereskin for their research assistantship. latest information communications technology (ICT), data analytic tools, and algorithms as part of their campaign strategies. While social media opened up new avenues to share information, facilitated political participation, and personalized communications, the digitization of elections has also led to challenges such as data privacy issues, use of bots, cyborgs, foreign interference, and disinformation ${ }^{1}$ that affect voting behavior and electoral integrity (Elchahabi and Gallagher

\footnotetext{
${ }^{1}$ Here, disinformation is used to refer to the deliberate creation and sharing of false information or "fake news" in contemporary use. The term misinformation refers to the inadvertent sharing of false information, while mal-information includes satire, manipulated, misleading content, hoax and false content, to genuine visuals or content taken out of its original context and disseminated online (Wardle 2017).
} 
2015; Stieglitz, Brockmann, and Dang-Xuan 2012; Enli and Skogerbø 2013).

Since the Cambridge Analytica scandal revealed foreign interference in the U.S. elections and Brexit referendum in 2016, there has been an intensified scrutiny of data breaches and reformulation of digital information policies and codes of conduct for parties, candidates, and voters to guide fair datadriven campaigning (Meredith 2018). As of 2016, at least 43 countries around the world have proposed or implemented regulations to tackle influence campaigns, disinformation, social media abuse, and election interference (Bradshaw, Neudert, and Howard 2018, 4). In Asia, governments and EMBs are likewise developing new legal frameworks and cybersecurity strategies to combat the spread of falsehood or deter hacking into government databases. Presently, East and Southeast Asia has one of the highest densities of social media users in the world. Yet, few studies have focused on this region's regulatory approaches to the "information disorder" (Bounegru et al. 2017). Even fewer have considered the readiness of the EMBs to manage digital campaigns and their impact on elections. What are the rules of the game on data-driven campaigns? How ready are the EMBs in addressing disinformation and influence campaigns in Asia?

To answer these questions, this article covers the region's regulatory approaches to data-driven campaigns and disinformation in elections, specifically examining three types of laws: campaign finance and online political advertisements, data protection, and anti-fake news laws. In Asia, social media have created unprecedented opportunities for the mass manipulation of opinions by both foreign and local groups, and actors that led to lawsuits, unfair elections, and even violence. In recent years, anonymous social media accounts have been reported in Cambodia, Vietnam, Myanmar, Thailand, Hong Kong, China, Sri Lanka, and Malaysia (Seiff 2018). Prior to the 2018 Malaysian elections, thousands of bots suddenly appeared to spread pro-government news (Seiff 2018), and trolls were found to spread harassment and propaganda in support of presidential candidate Rodrigo Duterte in the 2017 Philippines elections (Etter 2017). The digital disruptions were not limited to elections. In India, seven people were killed by a mob after a false story spread on WhatsApp accusing them of child trafficking (Goel 2018). In Myanmar, Facebook helped to spread hate speech and incite violence against
Rohingya Muslims (Barron 2018). In Sri Lanka, false rumors disseminated on Facebook incited mob violence against Muslim minorities (Goel, Kumar, and Frenkel 2018). In Bangladesh, false rumors of child abductions on Facebook and YouTube led to mob lynching of eight people (BBC News 2019). Given these tragic events and upcoming elections in Myanmar, South Korea, and Singapore, an inquiry on the readiness of the EMBs to manage malicious social media and its effects in Asia is timely and necessary.

This article addresses the impact of disinformation and data-driven campaigns by proposing an electoral management digital readiness (EMDR) index to compare the readiness of the ten EMBs in Asia to respond to digital disruptions during elections. Disinformation in elections is distinguished from falsehood or libel in traditional media, as online content spread through social media cannot be regulated in the same way as it lacks journalistic standards and unchecked information is sent anonymously and quickly (Price, Verhulst, and Morgan 2013, 150).

The cases selected for study include ten EMBs from Cambodia, Indonesia, Japan, Malaysia, Myanmar, the Philippines, Singapore, South Korea, Taiwan, and Thailand that hold national, multiparty elections, and exclude China, Vietnam, and Laos-one-party states without competitive national elections and that have stringent Internet laws (see Human Rights Watch 2018). Out of the ten cases, eight EMBs have introduced social media tools and apps on handheld devices to improve communications and increase voter information on changes to the legal framework, training, education, recruitment, or to provide reports of previous elections and other relevant legal information. However, the EMBs in Japan and Singapore have refrained from embedding social media buttons on their websites and still rely on traditional news media and channels to transmit electoral news. See Table 1.

This article focuses on the legal regulatory framework and readiness of the EMBs and governments governing social media, voter databases, online political advertisements, and campaign spending during the pre-election campaign period. While most EMBs in Asia have pre-existing rules regulating the scope, timing, and financing of electoral campaigns, some have amended or devised new rules to target social media use during campaigns, online advertising, and disinformation. See Appendix Table A1 for a list of Internet and social media regulations in Asia. The aim of this study is 
Table 1. Electoral Management Bodies and Social Media in East and Southeast Asia

\begin{tabular}{|c|c|c|}
\hline & Election management bodies & Social media use \\
\hline Japan & $\begin{array}{l}\text { Ministry of Internal Affairs and Communications } \\
<\text { http://www.soumu.go.jp/senkyo/index.html }>\end{array}$ & No \\
\hline Malaysia & $\begin{array}{l}\text { Election Commission of Malaysia (SPR) } \\
<\text { http://www.spr.gov.my/> }\end{array}$ & Facebook \\
\hline Philippines & $\begin{array}{l}\text { Commission on Elections (COMELEC) } \\
<\text { https://www.comelec.gov.ph/> }\end{array}$ & Facebook, Twitter, Google+, Tumblr \\
\hline Singapore & $\begin{array}{l}\text { Elections Department Singapore (ELD) } \\
<\text { http://www.eld.gov.sg/> }\end{array}$ & No \\
\hline S. Korea & $\begin{array}{l}\text { National Election Commission (NEC) } \\
\text { <http://www.nec.go.kr/engvote_2013/main/main.jsp> }\end{array}$ & Facebook \\
\hline Taiwan & $\begin{array}{l}\text { Central Election Commission (CEC) } \\
<\text { https://www.cec.gov.tw/> }\end{array}$ & Facebook, Google+ \\
\hline Thailand & $\begin{array}{l}\text { Election Commission of Thailand (ECT) } \\
<\text { http://www.ect.go.th/ect_en/> }\end{array}$ & Facebook, Twitter, YouTube \\
\hline Cambodia & $\begin{array}{l}\text { The National Election Committee (NEC) } \\
<\text { https://www.necelect.org.kh/english/> }\end{array}$ & Facebook, YouTube, Flickr \\
\hline Indonesia & $\begin{array}{l}\text { General Election Commission (KPU) } \\
<\text { http://www.kpu.go.id/> }\end{array}$ & Facebook, Twitter, YouTube, and Instagram \\
\hline Myanmar & $\begin{array}{l}\text { Union Electoral Commission (UEC) } \\
<\text { https://www.uec.gov.mm/ > }\end{array}$ & Facebook \\
\hline
\end{tabular}

to take stock of the new and amended legal statutes and provide a composite index based on four key criteria to compare the capacity of the EMBs to address digital threats in elections. The criteria include the type of electoral management model, presence of specific or new regulations governing online campaign and disinformation, confidence in the rule of law, and technological readiness of the digital economy.

The arguments are organized as follows. The first section surveys the challenges and efforts of regulating social media in elections. The second section introduces an online electoral management readiness index, the rationale, and method behind the selected evaluation criteria. Based on the index, the third section compares the strengths and weaknesses of the ten EMBs thematically, highlighting the new regulations on online campaigns, election advertising, campaign finance, data protection, disinformation, and expert evaluations of the rule of law and technological readiness in the ten selected countries. The final section summarizes the findings and concludes with the implications of this study for the quality of electoral integrity in Asia.

\section{CHALLENGES OF REGULATING SOCIAL MEDIA DURING ELECTIONS}

The proliferation of disinformation and data breaches raises urgent questions on who should and how best to regulate online speech, especially since the sources or hosts of malicious content are outside the national state borders (Aronson and Cowhey 2017; Johal and Crawford Urban 2017). Regulating social media during elections is even more challenging as it is difficult to identify the source of disinformation, verify the truthfulness of fabricated content, and stop the dissemination within a short campaign time frame (ACE 2018). The relationship between social media use and elections is also complicated by the fact that misinformation, disinformation, and mal-information can occur in any part of the electoral phases, depending on the degree to which the EMBs have adopted ICT such as biometric registration, electronic voting, or social media apps. ${ }^{2}$

Aside from improving voting experience, social media can also be abused by parties, candidates, or foreign agents to use online election advertisements, automated bots, or influencers to manipulate public opinion and alter electoral outcomes (Benkler, Faris, and Roberts 2018; Cahn and Cahn 2018; Jamieson 2018). Digital campaign techniques have evolved from banner and TV advertisements to harvesting personal data from Facebook, advertisements on

\footnotetext{
${ }^{2}$ There are 10 to 12 phases to the electoral process (ACE 2014). Figure 1 in the IDEA 2014 report is useful in showing how social media is used by the electoral management bodies (EMBs) to build political participation (Kaiser 2014, 43).
} 
social media platforms, and microtargeting to alter voting behavior (Taylor 2018; Rathi 2019). The rise of online advertisements and lax regulations governing political donations and campaign spending have encouraged the flow of "dark money" and foreign interferences (Oklobdzija 2019). New computational propaganda techniques now include the use of artificial intelligence (AI), automated bots to spread propaganda messages, and sophisticated software to hack into political parties' servers or voter registration databases (Senate 2018; Hersh 2015; Benkler, Faris, and Roberts 2018).

In response to the threats of election meddling and exploitation of personal data, Germany, Brazil, Spain, and a handful of African countries have passed new laws to regulate data scraped from social media accounts and online content (Funke and Flamini 2018). The new laws largely focus on compelling social media platforms or individuals to remove illegal content or face fines (Faiola and Kirchner 2017). In particular, the General Data Protection Regulation (GDPR) is powerful in scope and reach to protect EU citizens' personal data. ${ }^{3}$ Despite extending the extraterritorial reach of the data protection law, it remains unclear how a national legal framework would be effective without a transnational governance network or a cybersecurity monitoring system to ensure compliance. Outdated regulations and the involvement of foreign-based social media and data analytical companies complicate the monitoring of trolls, bots, and text messages. State surveillance of social media posts and messages may infringe on user privacy and freedom of speech laws under different jurisdictions. The other challenges concern liability and enforcement. If there are regulations to deem the content illegal, who is to adjudicate and be liable for the malicious content? The individual offender, the person who re-posts, or the social media platform that hosts the false content? The complexity and the lack of clear code of conduct have led to the proliferation of fact-checking organizations to act as arbiters for news outlets. Yet, the credibility of fact-checkers can be questionable, as the funders or reliability of fact-checking methods may be biased, inadequate, or partisan (Kessler 2016).

The legal statutes and laws in most countries are still slow in addressing the ethical use of computational propaganda techniques such as bots, "deep fakes," or fake audios and videos in campaigns (Allcott and Gentzkow 2017; Rabin-Havt and Media Matters for America 2016). Instead of being a "lib- eration technology" (Diamond 2010), social media has become a conduit for foreign interference and a tool for authoritarian regimes to assert "sharp power" and create chaos in democracies (Tenove et al. 2018; Walker and Ludwig 2017). It is impossible to address all the normative, legal, technological, and transnational governance issues. Here, this study will contribute to the debates by offering an index to assess the EMBs' responsiveness to the digital threats, especially during the pre-election phase, most vulnerable to influence campaigns. ${ }^{4}$

\section{AN ELECTORAL MANAGEMENT DIGITAL READINESS INDEX}

An EMB is an organization or a body tasked with managing all or some elements of the elections such as referendums. Its behavior depends on the electoral framework, political and social expectations, and the cultural environment within which each EMB operates (Catt et al. 2014, 10). Effective digital electoral governance requires a legal framework that is balanced with a system within which authority is exercised, and the practical realities of technology to address the internal and external digital interferences. The structure, mandate, and performance of the EMB also differs depending on the degree to which the body is an independent stand-alone institution or a unit within a larger state institution, or a mix of both. While there are many variations, International IDEA has identified three models of EMBs, namely: Independent, Governmental, or Mixed, widely used to compare the structure, financial accountability, and performance of EMBs. ${ }^{5}$

\footnotetext{
${ }^{3}$ While the General Data Protection Regulation (GDPR) does not directly regulate disinformation, the regulation is expected to improve transparency of digital companies and businesses in using personal data to target voters (Zuiderveen Borgesius et al. 2018, 90).

${ }^{4}$ The analysis excludes other phases of the electoral process that may have incorporated information communications technology (ICT) or social media such as in the digitization of voter registration, biometric data, or e-voting.

${ }^{5}$ Independent model refers to those where elections are organized and managed by an EMB which is institutionally independent and autonomous from the executive branch of government, and which manages its own budget. Governmental model is where elections are organized and managed by the executive branch of government through a ministry, and a mixed model refers to those with a dual structure which has a policy, monitoring, or supervisory EMB that is independent of the executive branch of government. See Catt et al. (2014, 5-9).
} 
Drawing from the extant body of literature from electoral studies and political communications, this article offers an index to compare the EMBs' readiness to address the digital threats during the preelection phase of elections in Asia (Cheeseman, Lynch, and Willis 2018; Dommett and Power 2019; Ufen 2015; Baldwin-Philippi 2017; Chester and Montgomery 2017). The composite index enables a rigorous identification of regulatory frameworks and best practices in governance responses, and integrates the key institutional and technical criteria at the nexus of digital challenges to electoral democracy. Practically, indices are widely recognized for their contributions to governance in complex transnational policy fields (Mazziotta and Pareto 2013; O'Connor 2015).

The proposed index consists of four key evaluation criteria, namely: (1) the type of EMB model; (2) presence of a clear legal regulatory framework governing online political communication, campaign finance, and disinformation; (3) respect for the rule of law as an indicator of the confidence in the capacity of the EMB and government to enforce the regulatory framework; and finally, (4) technological readiness of the digital economy to deal with online disruptions such as data breaches, hacking, and automated bots. This index focuses on these four criteria as they are key institutional features that would equip an EMB to respond effectively or coordinate with key state cybersecurity agencies to ensure that the key stakeholders such as parties, candidates, and social media companies comply with the rules of the game. Aside from updating the laws, it is necessary to consider the EMBs' capacity to enforce and ensure compliance and the technological capacity of the surrounding digital infrastructure to support, track, and respond to digital disruptions during the campaign period.

The indicators and measures of this index are drawn from publicly available sources such as International IDEA's classification of EMB model and election reports; statutory laws and electoral legislation related to online campaigns, campaign finance, data protection, online content; and cross-country indexes such as the World Bank (WB) Governance Indicator for the Rule of Law and Economist Intelligence Unit (EIU) Technological Readiness Ranking (Kaufman and Kraay 2019; Economist Intelligence Unit 2018). Given the space constraint, the analysis is limited to the new or amended legal and regulatory interventions in response to the spread of online disinformation, personal data, social media manipula- tions, and excludes the pre-existing penal code, defamation, sedition, blasphemy, incitement, or public mischief laws on hate speech, media censorship, or foreign interferences.

The index combines the qualitative and quantitative six individual data sources (v1-v6) into an aggregated digital readiness (DR) indicator for each country. The observed score for each source is expressed in a formula below, with each variable weighted equally:

$$
\mathrm{v} 1+\mathrm{v} 2+\mathrm{v} 3+\mathrm{v} 4+\mathrm{v} 5+\mathrm{v} 6=\text { EMDR }
$$

The aggregated EMDR score is the total score of all the individual data sources with a higher score denoting higher levels of readiness to respond to digital disruptions during elections. To begin with, the electoral management model (v1) is drawn from International IDEA's classification (governmental, mixed, or independent) and numerically scored based on a scale ranging from -1 to +1 , with a higher score denoting higher organizational capacity, autonomy, and resources to coordinate with key state cybersecurity or media agencies to monitor online content and ensure accountability. The different EMB models indicate the distance between the EMB and the government, and also the EMB's access to state cyber security infrastructure or agencies to detect digital electoral interference. The assumption is that "governmental" EMBs, where elections are managed by the Executive branch, will have the budget and jurisdiction to access a state's cybersecurity apparatus to monitor and detect digital irregularities during a campaign period. Hence, a "governmental" EMB receives a score of "1." On the other hand, an "independent" EMB is officially autonomous, expected to have its own technical expertise or in-house digital capacities to detect digital fraud or irregularities. An "independent" EMB model receives a score of " -1 " as it is unlikely to have the resources or digital expertise to independently detect irregularities at this stage, unless otherwise reported. A "mixed" EMB with varying degrees of access to state cybersecurity infrastructure will be scored " 0. "

The three individual data sources for online campaign, data protection, and disinformation law under online electoral rules (v2 to v4) are qualitatively assessed and numerically scored based on a scale ranging from -1 to +1 . The EMB that has specific laws or regulations governing online campaign 
advertising, political donation or finance (v2), data protection (v3), and anti-disinformation (v4) will each receive a score of " 1 "; those with existing laws but they are deemed too vague, arbitrary, outdated, or unenforced will be scored " 0 "; and those without any specific rule or regulation will receive a score of "-1."

As for the rule of law, the scores are drawn from the 2017 WB Governance Indicator, with higher values corresponding with better outcomes. ${ }^{6}$ The WB rule of law governance indicator is used as it has the aggregated ranking of reputable sources for rule of law such as the Economist Intelligence Unit Riskwire and Democracy Index, Global Integrity Index, and World Justice Project Rule of Law. ${ }^{7}$ Besides, it is one of the few indexes that tracks all the countries studied in this article. The WB rule of law indicator captures the perceptions of the extent to which agents have confidence in and abide by the rules of society, especially the quality of contract enforcement, property rights, the police, the courts, and of crime and violence. Hence, it is a great indicator to show if the key stakeholders are likely to respect and abide by the electoral regulatory framework, and that the laws are administered and enforced fairly and efficiently.

Finally, the measure of the technological readiness of the country is drawn from the Economist Intelligence Unit (EIU) Technological Readiness Ranking for 2018 to 2022 (Kovalik 2018; Hersh 2015; Benkler, Faris, and Roberts 2018). The EIU Technological Readiness Ranking is used as it compares 82 countries on three key categories that are essential to deal with digital threats, such as the access to Internet, digital economy infrastructure, and openness to innovation. It is a good proxy to indicate the overall readiness of the country's cybersecurity infrastructure as it includes e-government and cybersecurity capacity to monitor exchanges on social media and web portal accounts or cybercrimes. Both the WB rule of law and EIU technological readiness scores have been converted to -1 to +1 , with higher values indicating higher levels of technological and digital readiness. ${ }^{8}$

\section{COMPARING ELECTORAL MANAGEMENT DIGITAL READINESS IN ASIA}

Based on the earlier criteria, the ten EMBs in East and Southeast Asia may be classified into three broad levels of digital readiness: high (2 to 6), medium ( -2 to 2 ), and low ( -6 to -2$)$. As Table 2 shows, the EMBs with a high level of digital readiness include Singapore (5.67), South Korea (4.27), Japan (2.5), Taiwan (2.27), and Thailand (2.08). The EMBs with medium digital readiness with scores include Malaysia (1.6), the Philippines $(-0.16)$, and Indonesia (-1.39). Finally, the EMBs from Cambodia $(-2.98)$ and Myanmar $(-5.16)^{9}$ have low levels of digital readiness.

Comparatively, the EMBs with high digital readiness have clear and specific national legislation or electoral rules targeted at key stakeholders in the electoral processes to ensure that parties, candidates, voters, social media, or digital analytic companies use social media for political communication and campaigns in a transparent and accountable way. See Appendix Table A1. These EMBs operate in a surrounding environment where the rule of law is respected, enforced, and largely complied with by the stakeholders or risk sanctions. The EMBs with high digital readiness are more likely to have "governmental" or "mixed" models that make it easier to draw on the relevant state resources or cybersecurity agencies to monitor data breaches, hacks, and online threats. Vice-versa, the EMBs with medium or low levels of readiness lack the competence in one or all of the criteria. Notably, the EMBs from Thailand and Cambodia rated "independent" by IDEA also had reports of their autonomy being curtailed by the ruling governments. The following section will evaluate the strengths and weaknesses of the ten EMBs categorically.

${ }^{6}$ The World Bank's (WB's) scale ranges from -2.5 to +2.5 , while the Economist Intelligence Unit (EIU) Technological Readiness scale ranges from 1 to 10 . For the index, to ensure equivalent weight for all criteria, the WB and EIU scores have been converted to the -1 to +1 scale. The converted score $y$ in the new range $\left[-y_{\min }, y_{\max }\right]$ was adjusted from its original value $x$ in the original range $\left[-x_{\min }, x_{\max }\right]$, based on the following formula:

$$
y=y_{\min }+\left[\left(\frac{x-x_{\min }}{x_{\text {range }}}\right) y_{\text {range }}\right]
$$

Where $y_{\text {range }}=y_{\max }-y_{\min }$ and $x_{\text {range }}=x_{\max }-x_{\min }$ respectively. ${ }^{7}$ For WB governance methodology and analytical issues, see Daniel, Kraay, and Mastruzzi 2010.

${ }^{8}$ See footnote 6 .

${ }^{9}$ Technological Readiness scores are unavailable for Cambodia and Myanmar as both have small digital economies. 


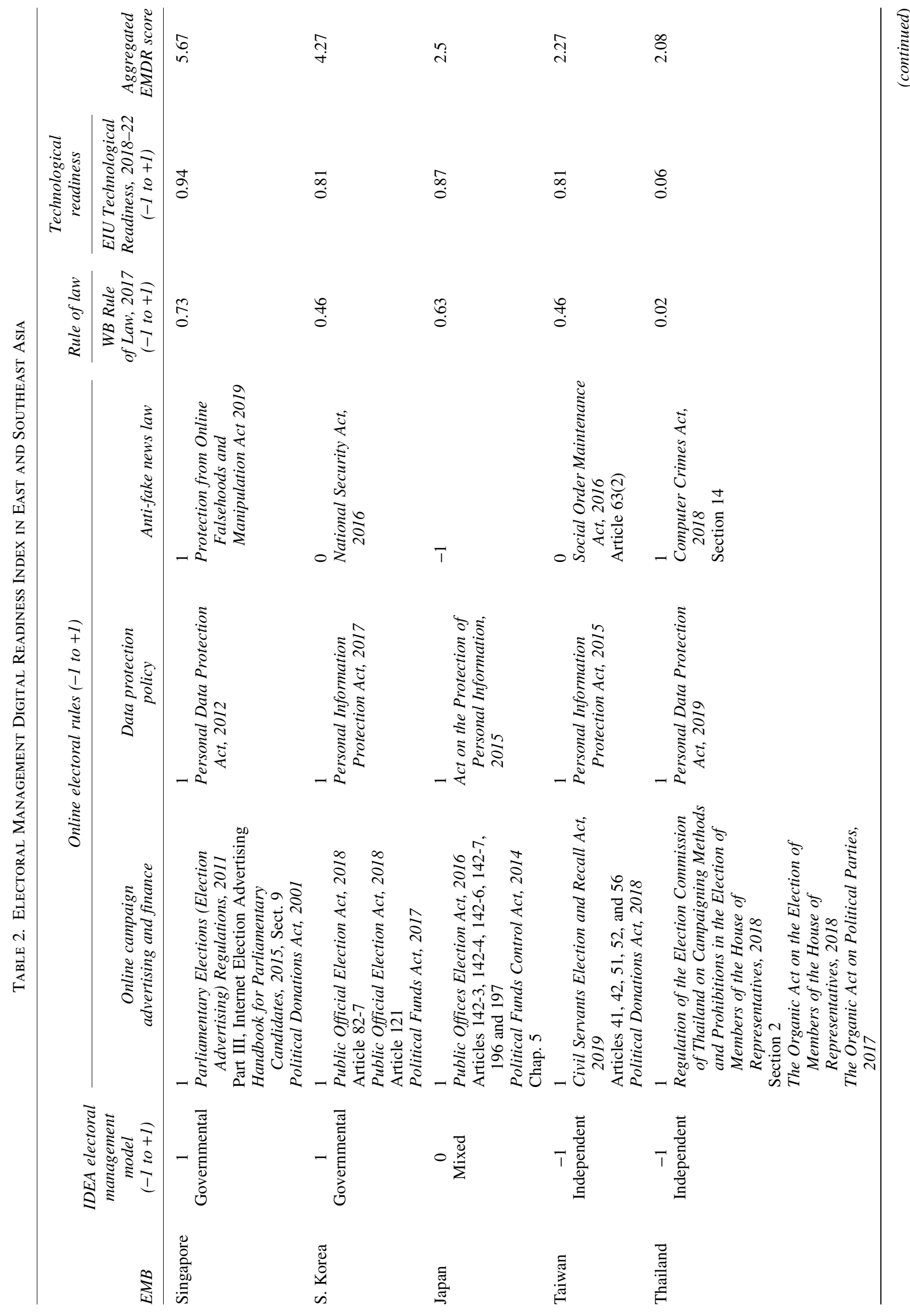




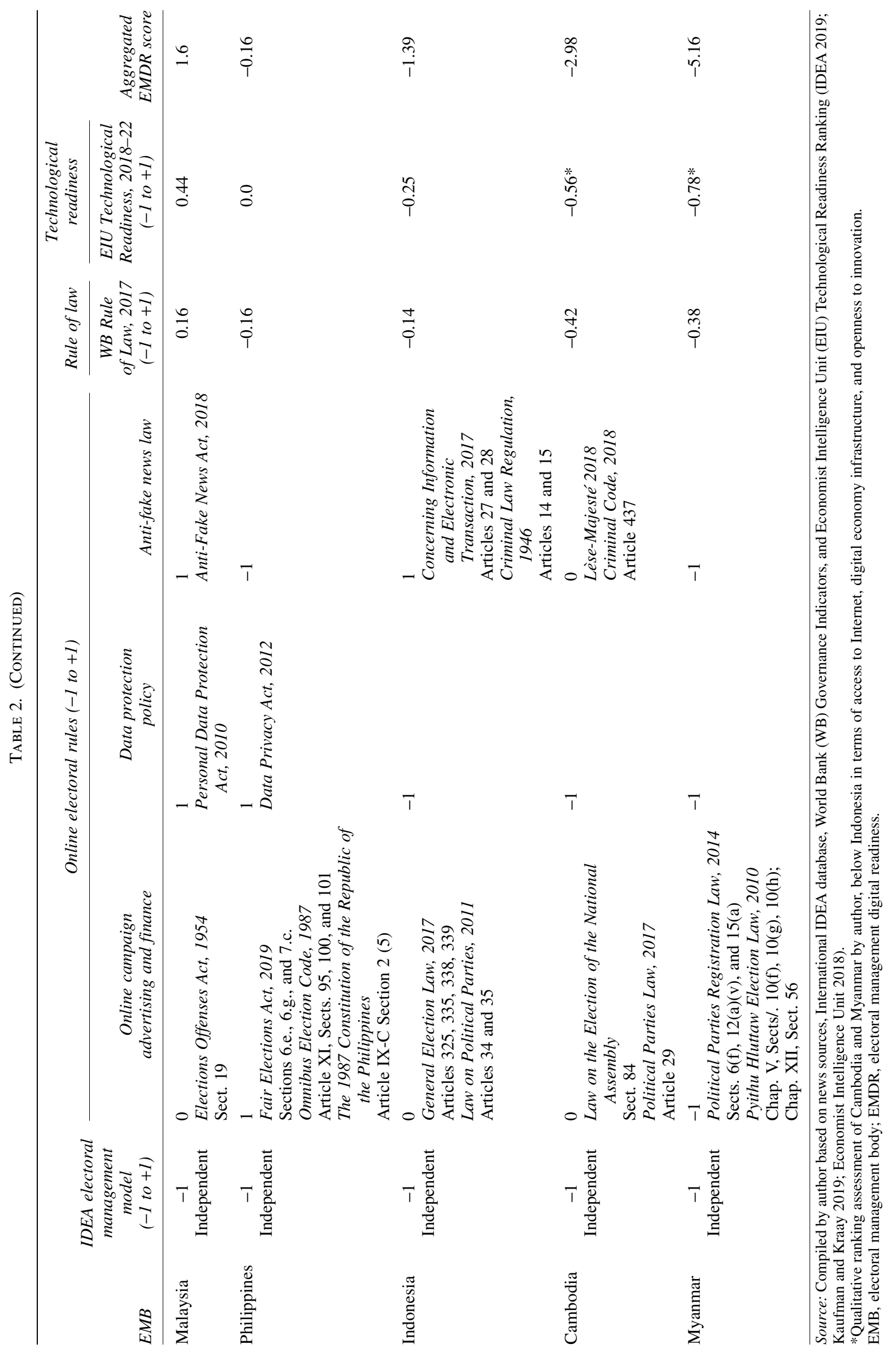


Online political advertisements and campaign finance

In response to the illegal campaign spending and threat of foreign interference, six EMBs (Singapore, South Korea, Taiwan, Japan, Thailand, and the Philippines) have developed specific rules and guidelines governing political advertisements and online campaign finance to improve transparency and accountability. See Appendix Table B1 for the electoral campaign and political donation rules and provisions in Asia. Despite having high Internet penetration in Japan (93.3\%) and Singapore $(83.6 \%)$ (Internet World Stats 2018), Japan ${ }^{10}$ and Singapore ${ }^{11}$ only lifted their ban on digital campaigning in 2013 and 2011, respectively. In Singapore, any online election advertising through e-mail, social networks, or blogs must display "relevant particulars" including the name and address of the publisher and the name and address of every person for which the election advertising is published (Parliamentary Elections [Election Advertising] Regulations 2001). The Singapore Elections Department (ELD) also has a "positive list" of permitted platforms for Internet Election Advertising and specific rules for Internet election advertising (e.g., podcasts, videocasts, blogs, and social networking sites) that require approval from the ELD (Elections Department Singapore 2015).

Similarly in Japan, after lifting its ban on online campaigns, ${ }^{12}$ any blog launched after a campaign must provide contact information, and campaign e-mails are to be sent only by political parties and candidates (with party website logos and notifications that are part of a campaign) within a short time period (14-17 days) (Mie 2013a). Japan has clear guidelines on political donations with specific limits on individual campaign spending depending on the constituency, type of election, and restrictions on anonymous donations to candidates. While anonymous donations can be made to parties, they must be under 1,000 yen (IDEA 2016). See Table 2.

In South Korea, online political advertising and financing are similarly strictly regulated under the 1965 Political Fund Act, which has since undergone 24 revisions. Since 2005, South Korean users have to verify their identity before contributing to electionrelated online discussion forums. ${ }^{13}$ In fact, its National Election Commission (NEC) only allowed Internet, e-mail, and text message campaigning on election day in 2017 (NEC 2017). NEC also bans any publication of material supporting or disapproving a candidate for 180 days prior to the election. To ensure compliance, it has an Internet Election News Deliberative Committee to monitor Internet election news to determine if any online press violates election law (ACE 2010). ${ }^{14}$

As Thailand was under military rule from 2014 to 2019, its media, including social media, has been under heavy monitoring and control since the military coup in 2014 (Yangyue 2014a; Sinpeng, O’Mahony, and Nyblade 2015). Support for anti-coup activities by liking a social media post constituted a crime, punishable by up to five years in jail. ${ }^{15}$ Thailand's Election Commission (ECT) ${ }^{16}$ (2018-present) installed by the junta-appointed National Legislative Assembly (NLA) has draconian rules to restrict social media for campaigning and established an "e-war room" to monitor candidates' behavior online. ${ }^{17}$

In Cambodia, the nominally independent National Election Commission (NEC) has not developed any clear guidelines concerning online campaigns and refused to draft campaign financing legislation (Amaro 2017). Instead, before the 2018 elections, the government clamped down arbitrarily on the media while the NEC adopted a vaguely worded Code of Conduct to prohibit the media from broadcasting news which

\footnotetext{
${ }^{10}$ After the revision of the Public Offices Election Law in 2013, candidates in Japan were allowed to update their home pages, blogs, and social media with election campaigning (Tsuruoka 2018).

${ }^{11}$ Singapore's election laws were amended in 2011 to give parties and candidates more freedom to advertise online through podcasts, video, blogs, instant messages, and social networks (Mydans 2011).

${ }^{12}$ In Japan, door-to-door canvassing was banned for almost a hundred years while leaflets are restricted to 70,000 sheets per person. TV ads for candidates are still banned. Individuals who violate the electoral campaign restrictions face up to two years in prison and fines up to $¥ 500,000$ (Mie 2013b).

${ }^{13}$ See Article 93(1) of the Public Official Election Act (Act). This Act was deemed unconstitutional in 2011.

${ }^{14}$ The 2007 Information and Communications Network Act requires every Internet portal to verify their users' identities and online news media (Tsuruoka 2018).

${ }^{15}$ Charges were filed against former Minister Chaturon Chaisang for his anti-coup statements (Prachatai 2014).

${ }^{16}$ The Commission has refused to investigate a campaign finance scandal involving the military regime's proxy, the Phalang Pracharath Party, but dissolved an opposition party, Thai Raksa Chart (Tonsakulrungruang 2019).

${ }^{17}$ Facebook banned foreign election advertisements before the 2019 poll under the government's request (McDermid 2019). Parties have to notify the Commission of the information they put on the platforms (Ellis-Petersen 2019).
} 
led to more "confusion and confidence loss in the elections." ${ }^{18}$ Additionally, the government blocked 17 websites while the NEC requested parties and media to "remain silent" for 24 hours prior to elections. According to Freedom House, the authorities penalized 40 cases of online freedom of expression violations between April 2017 and March 2018. The scale of arrests alongside surveillance led to a heightened sense of self-censorship and doubts of the NEC's impartiality (Freedom House 2018).

Meanwhile in the Philippines and Taiwan, legislators finally amended the elections acts to regulate social media use and political advertisement due to the widespread threat of bots and foreign interference. In the Philippines, the Commission on Elections (COMELEC) included social media propaganda in the Republic Act No. 9006, or the Fair Elections Act, to outline the maximum sizes allowed for online political ads for each candidate. All online advertisements (paid and free) cannot "be published more than three times a week per website during the campaign period" (Fair Elections Act 2018). Candidates who belong to a party are only allowed to spend PHP3 per voter while independents are allowed to spend PHP5 per voter. Political advertisements also need to identify the source, and the words must include "advertisements paid by" followed by the name and address of the payor. However, there remains no limit on the amount that an individual or companies can donate in the Philippines. ${ }^{19}$ This suggests that the oligarchs and big corporations can have disproportionate amounts of influence in electoral politics and "dark money" may still be funneled to influence elections (Sy 2019; Aspinall et al. 2016).

In view of the 2020 elections in Taiwan and threats of "red media" - a term used to describe orchestrated disinformation and opaque online proBeijing Chinese sources (AFP 2019), Taiwan's Central Election Commission (CEC) amended its Civil Servants Election and Recall Act to handle fake opinion polls and ban local media and Internet service providers from carrying campaign advertisements funded by foreign sources (Ministry of Interior 2019). All election ads must state the name of the advertiser, not just the media organization as is currently required. This is to counter the use of fake polls to influence voter sentiments and to deter the Chinese government agencies from funding China-based Taiwanese businesses to exert influence. Recently, legislators also amended its National Security Act and passed the Cybersecurity Act to criminalize foreign influence and malicious cyberattacks on its public and private sectors. Under the amended laws, media organizations and advertising brokers are responsible for verifying the source of the funding for election ads (Huang and Li 2018; Jennings 2019b; Zhang 2019).

In contrast, the EMBs in Indonesia, Malaysia, and Myanmar do not have specific guidelines governing social media use or online political advertising. While there are existing or amended campaign finance rules, the caps on political donations are either very high or unenforced. For example, in Indonesia, while campaign expenditure is regulated by the General Election Commission (KPU) and stipulated in General Election Law 2017, Articles 325 and 335 , the campaign funding limits for presidential candidates and parties are capped at very high levels (IFES 2018, 5). The Law on Political Parties 2011, Article 35 also sets a high donation limit of 1 billion rupiah (US\$82,000) for individuals and 5 billion rupiah (US\$600,000) for corporations. To prevent foreign interference, Article 339 of General Election Law 2017 prohibits funding from foreign sources and requires candidates to disclose the identity of donors by providing clear information and tax returns. In practice, the enforcement of these campaign finance laws is lacking in Indonesia (Sukma 2019). Money politics, vote buying, and excessive spending are a persistent problem and notoriously difficult to regulate (Aspinall et al. 2017). In part, this is because of the poor quality of documentation and low transparency in financial reporting that prevented proper auditing by the KPU (Sukma 2019).

In Malaysia, the Election Offences Act limits election expenditure of parliamentary seat candidates. However, parties do not have spending caps and there is no ban on anonymous, foreign, or corporate donations, which allows parties to have unequal access to business donations through governmentlinked companies (Gomez 2018; Ufen 2015). While parties must disclose their funding under the Societies Act (1960), they are not required to disclose their funding source (Muzaffar 2018). This loophole in campaign finance law explains in part

\footnotetext{
${ }^{18}$ See Section 84 of the Law on Election of Members of the National Assembly (2015).

${ }^{19}$ See Section 13 of the Republic Act No. 7166 (RA 7166).
} 
the corruption scandal that the former Malaysian Prime Minister Najib Razak is being investigated for, allegedly receiving US\$700 million in donation from the Middle East in 2013 (Lamb 2018).

Meanwhile in Myanmar, the electoral governance and campaign finance regulatory framework is still rudimentary and lacks transparency or oversight. Since democratization in 2010, Myanmar has only conducted three elections. There is a lack of financial disclosure as parties are only required to archive their account books, while candidates are not required to disclose financial spending to the Union Election Commission (UEC). Besides, the candidates' spending limits also do not take into account the sizes of constituencies or makeup of the different parliamentary bodies (Sone 2018).

\section{User data protection policies}

Transparent use of personal data is critical to electoral integrity. Voter registration databases are vulnerable to cyberattacks, as EMBs are always removing and updating personal data. Further, the software and encryption of voter databases are typically outdated and ill-equipped to defend themselves against elite hackers. Ransomware-style attacks can occur that lock an infected computer system or delete data until payment, usually in the form of cryptocurrency, is sent to the hacker (Bing 2019). None of the selected Asian countries studied have the same GDPR-type of rule to protect personal data. However, the governments in Japan (Act on Protection of Personal Information, 2017) ${ }^{20}$ Malaysia (Personal Data Protection Act, 2013), ${ }^{21}$ the Philippines (Data Privacy Act, 2016), ${ }^{22}$ Singapore (Personal Data Protection Act, PDPA, 2012), ${ }^{23}$ South Korea (Information Protection Act, 2011), and Taiwan (Personal Data Protection Act [Amended], $2015)^{24}$ have introduced user data protection policies with varied degrees of accountability and enforcement mechanisms to safeguard personal data from business operators. For example, Japan established the Personal Information Protection Commission (PPC), a central regulatory authority with enforcement powers backed by penal sanctions to require business operators to obtain consent from the data subject (Lovells et al. 2017); South Korea's Information Protection Act prevents the transfer of data to another country; while the Philippines Data Privacy Act includes a compulsory 72-hour personal data breach notification. Comparatively,
Taiwan's Personal Data Protection Act is vague and does not spell out any extraterritorial effect or right to be forgotten. See Table 2.

In particular, Singapore's Personal Data Protection Act is the only known act in the region that has an advisory guideline that extends the collection of use and disclosure of user data beyond business transactions to elections (Personal Data Protection Commission Singapore 2017). Specifically, the PDPA requires parties and candidates who collect, use, or disclose the personal data of individuals to comply with the rules governing the collection, use, disclosure, and care of personal data in electronic and non-electronic forms. ${ }^{25}$ Aside from Singapore, it is unclear if the data protection policies in other countries extend to the EMBs or non-economic organizations such as parties or candidates who hire data analytics companies, or malicious agents using ransomware or micro-targeting the voter registration database.

The lack of specific voter data protection policies coupled with the use of social media apps on handheld devices or computers presents loopholes in the electoral processes as personal data transmitted during political communications may be vulnerable to harvesting, hacking, or manipulative messaging. For example, in 2016, the Philippines' COMELEC was hacked and defaced by two hacker groups. COMELEC's entire database of 55 million registered voters was leaked online, making it one of the biggest government related data breaches in history (Hern 2016). ${ }^{26}$ In 2019, ahead of Indonesia's presidential elections, KPU reported 10 to 20 automated attempts a day to hack into the data of a 187 million voter list (Lamb 2019). Even with a data

\footnotetext{
${ }^{20}$ For full details of the Act on Protection of Personal Information, see IFES $(2018,5)$.

${ }^{21}$ Malaysia's Personal Data Protection Act was enacted in 2013. See Personal Data Protection Act (2010).

${ }^{22}$ For details of Data Privacy Act (DPA), see Data Privacy Act (2012).

${ }^{23}$ For details of Singapore's Personal Data Protection Act (PDPA), see Personal Data Protection Commission Singapore (2012).

${ }^{24}$ For details, see Taiwan's amended Personal Data Protection Act (National Development Council 2015).

${ }^{25}$ The difference between GDPR and PDPA is Singapore's lax definition of consent, without the individual giving consent, as long as the personal data is voluntarily given.

${ }^{26}$ In Hong Kong's chief executive election in 2017 , the personal information of 3.7 million voters was compromised after the Registration of Electoral Office reported two missing laptop computers (Ng 2017).
} 
protection policy and Cyber Security Agency, Singapore suffered a few severe data breaches, compromising personal data of 1.54 million health care patients in 2018 and, later, information of 14,200 HIV patients and other education data in 2019 (Tham 2019). These data breaches show that in addition to building legal regulatory frameworks, more resources and training are needed to update security software, encrypt sensitive data, and train election administrators to improve best practices to enforce online electoral security.

\section{Anti-disinformation laws}

Governments in Asia have proposed or implemented legislation targeting disinformation that undermines national interests. ${ }^{27}$ Out of the ten cases studied in this article, three (Cambodia, Malaysia, and Singapore) have adopted new or specific antidisinformation laws while five others (Indonesia, South Korea, Singapore, Thailand, and Taiwan) have amended pre-existing national security or cybersecurity laws to address disinformation. Meanwhile, a proposed bill to amend the AntiFalse Content Bill in the Philippines to address malicious online content was rejected in the parliament. Thus far, only Japan and Myanmar have not drafted any legislation or expanded laws to address disinformation. See Table 2.

The anti-disinformation laws in Malaysia and Singapore are designed to target and compel social media companies and offenders to remove content or face hefty penalties and fines. In February 2018, the Cambodian parliament also passed a vaguely worded Lèse Majesté law, as an amendment to the Criminal Code (Article 437) to make it illegal to defame, insult, or threaten the king. ${ }^{28}$ Further constitutional amendments also obligate every Khmer citizen to "uphold the national interest" and prohibits citizens from conducting any activity that "directly or indirectly affect the interests of the Kingdom of Cambodia," which can be applied to online activities and criticisms of government policies (Hoekstra 2018).

In Malaysia, concerns with the opposition's social media activism and negative online coverage on the former PM Najib's involvement in 1MBD corruption scandal drove the parliament to introduce the Anti-Fake News Act (AFNA), days before its 14th general election in 2018 (Leong 2018b; Lourdes 2018). The AFNA empowers the government to jail anyone up to 10 years for knowingly creating, distributing, or publishing "fake news," defined to include "any news, information, data and reports" that are "wholly or partly false" (Anti-Fake News Act 2018). ${ }^{29}$ While the AFNA criminalizes online disinformation, the creation of false accounts using Facebook or WhatsApp in elections are unregulated (Lim 2017; Sani 2014; Yangyue 2014b). ${ }^{30}$ Since 2008, "cyber-troopers" or paid social media experts were used by the former ruling Barisan Nasional (BN) to run fake social media accounts to counter opposition campaigning. In the 2013 general election, Cambridge Analytica was found to have assisted the BN government to influence its campaign through a web of shell companies and targeted messaging campaign ads (Leong 2018a; Lamb 2018). ${ }^{31}$ Thus far, efforts by the new Pakatan Harapan government to repeal the AFNA have failed to pass the Senate (International Federation of Journalists 2018).

On April 1, 2019, the Singapore Parliament adopted a powerful Protection from Online Falsehoods and Manipulation Act (POFMA) to add to its arsenal of media, defamation, and sedition laws to give the government sweeping powers to issue correctives and compel social media companies to take down misleading or false statements or face a fine of up to $\mathrm{S} \$ 1$ million (Protection from Online Falsehoods and Manipulation Act 2019). Aside from having extraterritorial reach, the POFMA also criminalizes the making or use of bots (computer programs for running automated tasks) that transmit a false statement of fact. ${ }^{32}$ In addition,

\footnotetext{
${ }^{27}$ All the ten selected countries have pre-existing defamation laws that may be used to prosecute offenders that post false statements on digital platforms.

${ }^{28}$ For the English translation of Article 437 of the Criminal Code and other relevant press laws, see (SEAPA 2019).

${ }^{29}$ The Anti-Fake News Act (AFNA) has extra-territorial power. Sulaiman was the first person charged under the AFNA, who claimed in a YouTube video that police took 50 minutes to respond to the shooting of a Palestinian lecturer (Deahl 2018).

${ }^{30}$ The Malaysian government plans to regulate political funding but no details are available (Anis and Chung 2018).

${ }^{31}$ To counter the Barisan Nasional's (BN's) social media tactics in the 2018 general election (GE), voters turned to Twitter to boost voter turnout. Hashtags such as @CarPoolGE14 and \#PulangMengundi (return to vote) were used to support overseas voters facing flight scheduling difficulties to return to vote. ${ }^{32}$ Section 8 of the Protection from Online Falsehoods and Manipulation Act (POFMA) prohibits a person in and outside of Singapore from "communicating, by means of the bot, a false statement of fact in Singapore" (Singapore Statutes Online 2019b).
} 
amendments were also made to the existing Protection from Harassment $\mathrm{Act}^{33}$ to criminalize doxing, cyberbullying, stalking, and online harassment (Singapore Statutes Online 2019a).

Instead of designing new laws, legislators in Indonesia, South Korea, Thailand, and Taiwan amended or extended pre-existing laws to deal with malicious social media. For example in Indonesia, concerns with the spread of disinformation targeting presidential candidate Joko Widodo led to the legislators revising the Criminal Code, Articles 14 and 15 to provide that "[a]ny person who broadcasts fake news or hoaxes resulting in a riot or disturbance shall be punished with a maximum imprisonment fine of Category III" (Indonesian Criminal Code [Kitab Undang-Undang Hukum Pidana] 1945), or those who cause a "public disturbance by spreading fake news" can be imprisoned for up to ten years. Earlier, Indonesia amended its Concerning Information and Electronic Transaction (ITE) Law in December 2016 that included Article 27 that prohibits distribution or transmission of electronic documents with contents of defamation, and Article 28 that punishes those "who knowingly and without authority disseminates false and misleading information" (Law Concerning Electronic Information and Transactions 2008). ${ }^{34}$

Despite the legal provisions in Indonesia, more than 1,200 online disinformation or fake contents were detected, with 130 related to the presidential candidates and parties between August 2018 and March 2019 alone (Straits Times 2019). While Articles 14 and 15 of the revised Criminal Law punish distributors of falsehood, the holding of social media accounts in false names is not prohibited, unless a real person is being impersonated (Potkin and Costa 2019). Teams of "buzzers" or social media influencers were hired by both presidential candidates ahead of Indonesia's hotly contested 2019 presidential elections. The campaign teams from both Jokowi and his challenger, retired general Prabowo Subianto, hired dozens of "buzzers" or "secret cyber army" to hold hundreds of personalized social media accounts to share fabricated, hoax, and inflammatory stories as part of their campaign (Today Online 2018; Irawanto 2019). ${ }^{35}$ The fact that Facebook banned holding accounts under false names and political advertisements from outside Indonesia has done little to slow down disinformation (Al Jazeera 2019).
In Thailand, after lifting the ban on online campaigning in August 2018, the Thai military-backed government has turned to existing Lèse Majesté ${ }^{36}$ law and amended the Computer Crime Act in 2016 to restrict online speech before its 2019 elections. The amended Computer Crimes Act criminalizes offenses that are "likely to cause damage to the public," including partially false data and data that harms national security or causes public panic, allowing authorities to request the removal of online content deemed morally offensive or a threat to national security, without court approval (Computer Crimes Act 2007).

The South Korean National Assembly has several law amendments pending that are aimed at curbing misinformation and the use of bots to manipulate online comments. ${ }^{37}$ About half of the proposed amendments relate to the Promotion of Information and Communications Network Utilization and Information Protection Act, and grant information technology (IT) service providers the right to remove disinformation (Song 2017). Disinformation seriously affected South Korean politics as politicians, including the indicted former President Lee Myung-bak, were accused of supporting disinformation operations to smear celebrities with opposing views (Yim 2018). In 2018, the ruling Democratic Party launched a disinformation countermeasure task force and filed around 500 complaints against the people disseminating problematic content (Funke 2018). In Taiwan,

\footnotetext{
${ }^{33}$ The Anti-Harassment Act has been used by the government to sue individuals running a sociopolitical site, the Online Citizen, and another individual who had made allegations against the Ministry of Defense (Lum 2017).

${ }^{34}$ The amendment also includes the right to be forgotten, where a person has the right to request that an ESP delete any "irrelevant" electronic information or documents under the ESP's control (Molina 2016).

${ }^{35}$ The "buzzers" also hire subcontractors. A spokesman for Prabowo's campaign team was arrested for spreading fake news and treason under the Articles 14 and 15 of the Criminal Law (Marhaenjati and Nathalia 2019).

${ }^{36}$ Under Thailand's Lèse Majesté law, those found guilty of insulting the monarchy face up to 15 years in prison (Lefevre 2018). In January 2017, the National Security Council (NSC) cooperated with Laos and arrested a handful of people for disseminating anti-royal content through radio and social media. ${ }^{37}$ Korea's Constitutional Court struck down registration requirements for online news agencies in 2015. It amended its Act on Promotion of Information and Communication Network Utilization and Information Protection Bill to enable information technology (IT) service providers and web portals the right to delete news stories that are proven to be fake (Song 2017).
} 
after much debate and resistance, the legislators finally added a clause in Article 63 to the Social Order Maintenance Act to criminalize mis- and disinformation. ${ }^{38}$

\section{Rule of law}

The discussion on the rules governing online campaigns, data protection, and disinformation shows that key stakeholders such as parties, candidates, and international media companies need to have confidence in and abide by the rule of law in order for the regulatory framework to work. While not a perfect measure, the longstanding WB's governance indicator offers a way to assess the level of confidence and robustness in a country's rule of law. Based on 2017 rule of law scores, six countries have above a "0" score, namely: Singapore (0.73), Malaysia (0.16), Japan (0.46), South Korea (0.63), Taiwan (0.46), and Thailand (0.02). See Table 2. The high rule of law score in these countries coupled with EMBs with "governmental" or "mixed" electoral models (Singapore, South Korea, and Japan) are more likely to have higher capacity to enforce the online campaign or anti-disinformation rules and capacity to prosecute errand offenders and companies.

Studies show that countries with weak rule of law are more likely to experience electoral manipulation and fraud (Birch 2012; Simpser 2013; FortinRittberger 2014). According to the World Bank's rule of law index, the EMBs with low rule of law scores such as the Philippines, -0.0; Indonesia, -0.25 ; Cambodia, -0.56 ; and Myanmar, -0.78 are more likely to have the rules routinely broken or inconsistently enforced. Besides, given the "independent" management model of the EMBs in all these countries, the EMBs are less likely to have the necessary institutional support or resources to provide oversight to ensure accountability, transparency, and compliance.

\section{Technological readiness}

Based on the EIU technological readiness ranking for 2018 to 2022, the countries deemed to have higher levels of technological readiness to deal with digital disruptions are Singapore (0.94), South Korea (0.81), Japan (0.87), Taiwan (0.81), Malaysia (0.44), and Thailand (0.06). These countries are considered to have technological readiness especially in the areas of e-governance, accurate record keeping, robust regulations, digital innovation, and research infrastructure. See Table 2. Out of these, the EMBs with "governmental" or "mixed" models, such as Singapore, South Korea, and Japan, are more likely to be better equipped and responsive as the EMBs are embedded within government structures. This means they are likely to have an easier time coordinating with other cybersecurity agencies to respond to hacking or the spread of online disinformation. For example, South Korea invested substantial budget to developing cyber technologies based on artificial intelligence and big data analytics to prevent stealing of personal data. The Korean Communications Standards Committee, the Korea Internet and Security Agency, and NEC are collaborating to strengthen monitoring efforts, targeting exchanges of social media and web portal accounts, to deter sharing of disinformation and illegal campaign tactics adopted through fake online accounts (Yim 2018). Similarly, Singapore has a Cyber Security Agency under the Ministry of Communications and Information to protect the government's critical services such as energy, banking, and health sectors. Given the Cyber Security Agency extension of its Personal Data Protection Act to elections, it is likely that the ELD under the prime minister's office will have access to other ministries to provide oversight and monitor online abuses and manipulations during elections.

Comparatively, countries with low levels of technological readiness, with " 0 " or below " 0 " scores, include Philippines (0.0), Indonesia ( -0.25$)$, Cambodia (-0.56), and Myanmar (-0.78), and the EMBs are still in the early stages of developing their cybersecurity infrastructure and technology. For example, Indonesia formed a new National Cyber and Encryption Agency (NCEA) to tackle cybercrime, online radicalism, and hoaxes. In 2018 alone, Indonesia had more than 200 million cyber-attacks (Chairill 2019). To fight the "weaponization" of religious conservative views, the government created an Internet censorship system that will automatically block pornography and other content deemed to be unsuitable by the government (including gambling, terrorism, fraud, hoaxes, and

\footnotetext{
${ }^{38}$ More than 110 people had been arrested under the new law as fears of Chinese-funded misinformation campaign increased for the 2020 presidential elections. Under the law, people who publish misinformation online could be punished by up to three days in jail or a fine of up to $\$ 30,000$ Taiwan dollars (US\$1,000) (Jennings 2019a).
} 
disinformation) (Tisnadibrata 2018). Given the KPU's independence model, it is unclear if the KPU can turn to NCEA to deal with online threats. Finally, both Cambodia and Myanmar are not ranked by the EIU due to their small digital economies. Given their low network coverage and research capacity in high-technology sectors, their EMBs' technological capacity to monitor or stem the spread of malicious social media is likely to be very weak.

\section{IMPLICATIONS}

This study has proposed a composite index to assess the regulatory framework and readiness of ten EMBs to respond to digital disruptions in Asia. The index helps to lay out key criteria to systematically compare the specific regulations and rules governing social media use in election campaigns, advertising, political spending and donation rules, data protection, and the spread of disinformation during elections. Additionally, it also considers if the EMBs are perceived to be supported by strong rule of law and technological readiness based on international cross-country surveys and rankings. Based on the evaluative criteria set out in the index, this study finds five EMBs in Singapore, South Korea, Japan, Taiwan, and Thailand to have high levels of digital readiness; the EMBs in Malaysia, Philippines, and Indonesia to have medium levels; and two EMBs in Cambodia and Myanmar to have low levels of readiness to deal with online disruptions and influence campaigns.

This study highlights a few theoretical, practical, and technological implications for the region's electoral integrity. First, amending legislation and electoral rules alone is necessary but insufficient to governing the "information disorder." A rulesbased analysis alone cannot capture the effectiveness of the EMBs to fulfil their obligation to ensure a free and fair election and prevent online exploitation. This regional comparison shows that EMBs need to build technical expertise and resources to coordinate with relevant cybersecurity bodies and fact-checking organizations to monitor and ensure that key stakeholders comply with the online rules of the game. For example, in Indonesia, despite the legal provisions, the KPU's poor documentation, and weak monitoring and auditing mechanisms have led to excessive campaign spending and weak enforcement of campaign laws and violations of ITE laws. Indonesia also shows that the EMB and the government agencies need to embark on concurrent efforts to promote digital media literacy and improve the capacity of voters to identify and report violations of advertising or campaign spending rules and fact-check disinformation. More collaboration between the EMBs, media tech companies, and civil society to develop cybersecurity infrastructure, non-partisan fact-checking, and reporting mechanisms is necessary.

Second, the current online regulations in Asia have overlooked sources of disinformation coming from the ruling elites. The focus of the new anti-disinformation laws and amended criminal code in Malaysia and Cambodia specifically target social media platforms and offenders to remove malicious or fake content. While the extraterritorial reach of the law may compel foreign-based social media companies to take down content or ban foreign-funded election advertisements, it is unclear if the EMBs or governments have the resources to deter or prosecute foreign agents outside of the state jurisdiction. Besides, the use of trolls and cybertroopers in the Philippines, Indonesia, and Malaysia show that sources of disinformation can originate from the incumbent government. The culpability of the ruling elites engaging in information warfare against challengers raises questions on the intent of the antidisinformation law and the ability of the EMBs to respond effectively if they are not fully independent, technologically equipped bodies.

Further, the anti-disinformation laws may be abused and undermine electoral integrity, especially if the rule of law is weak. For example, the vaguely worded lèse-majesté laws in Cambodia and Thailand were used to intimidate and silence opposition leaders. Further, loopholes in Indonesia's Articles 14 and 15 of the Criminal Law revised to punish distributors of disinformation but not the holders of social media accounts in false names also fail to deter campaign teams from hiring "buzzers" to spread propaganda. Unclear definitions of disinformation or malicious content that undermines national interests may lead to a resurgence of electoral authoritarianism in the region and contribute to the global backlash against liberal democratic world order. Even in Singapore with a strong rule of law, POFMA has been used 
against political dissidents ${ }^{39}$ the opposition Singapore Democratic Party (SDP), ${ }^{40}$ and socio-political websites ${ }^{41}$ since the Act came into effect on October 2, 2019. Singapore's use of POFMA has been criticized by human rights lawyers and academics for having the "unintended detrimental consequence" of suppressing academic freedom and freedom of expression. ${ }^{42}$ Thus, abusing the rule of law under the guise of combatting disinformation is a real threat to democracy.

Third, the national data protection policies need to be extended to the EMBs or non-economic organizations such as parties or candidates, data analytics companies who may use ransomware, or microtarget voters. Aside from Singapore and Japan, none of the countries studied have the extraterritorial reach to protect personal data. Most EMBs that store voter registration data are ill-equipped to defend themselves against elite hackers. Given the loose campaign rules and political donation restrictions and high social media use in the Philippines, Malaysia, and Indonesia, the EMBs in these countries are vulnerable to cyberattacks and hacks. The data breaches in Singapore and hacking into voter databases in the Philippines and Indonesia show extra resources and attention are needed to update security software, encrypt sensitive data, and train election administrators to improve best practices and oversight to enforce online electoral security.

\section{CONCLUSION}

The electoral management digital readiness index offered in this study is a first step to systematically assess and compare the regulatory framework and strengths and weaknesses of the EMBs in addressing disinformation and data-driven campaigns. The study of the ten EMBs in East and Southeast Asia shows that they are at different stages of readiness to respond to digital threats as the autonomy, resources of the EMBs differ. Further, whether the EMB is supported by a strong rule of law and adequate digital infrastructure and technology also matters. Regulating social media use is especially challenging during elections as it is difficult to identify sources of disinformation and stop the dissemination quickly. One way to improve the timeliness of fact-checking and removal of malicious content would be for the EMBs to collaborate with social media companies and fact- checking organizations to flag and curb the flow of disinformation and fake accounts. Further, more investment in cybersecurity infrastructure, machine learning, and data analytics tools can also help to automate detection of fake accounts or malicious content. A multi-pronged approach that involves different stakeholders, rather than relying on the state, is imperative to improve electoral integrity.

\section{REFERENCES}

Academia | Sg. 2019. "Academics Against Disinformation." Academia | Sg (blog), April 13. <https://www.academia.sg/ pofma/>.

ACE. 2010. "Korea, Republic of: Public Official Election Act." ACE Electoral Knowledge Network. <http://aceproject.org/ ero-en/regions/asia/KR/korea-republic-of-public-officialelection-act/view>.

ACE. 2014. "Electoral Management: Electoral Cycle." ACE Electoral Knowledge Network. <http://aceproject.org/aceen/topics/em/ema/ema06>.

ACE. 2018. "Media and Elections." ACE Electoral Knowledge Network. <https://aceproject.org/ace-en/topics/me/onePage>.

Agence France-Presse (AFP). 2019. "Taiwan Set for ProMainland Fake News Deluge Before Presidential Poll." South China Morning Post, June 27. <https://www.scmp .com/news/china/politics/article/3016312/taiwan-set-promainland-fake-news-deluge-its-elections $>$.

Al Jazeera. 2019. "Facebook Bans Foreign Political Ads Ahead of Indonesia Elections." Al Jazeera, March 5. <https:// www.aljazeera.com/news/2019/03/facebook-bans-foreignfunded-ads-indonesia-election-190305074956785.html>.

Allcott, Hunt, and Matthew Gentzkow. 2017. "Social Media and Fake News in the 2016 Election." Journal of Economic Perspectives 31(2): 211-36. <https://doi.org/10.1257/ jep.31.2.211>.

Amaro, Yesenia. 2017. "'Law Needed' on Campaign Spending." Phnom Penh Post, June 5. <https://www.phnompenhpost .com/politics/law-needed-campaign-spending $>$.

\footnotetext{
${ }^{39}$ Opposition member Brad Bowyer was the first person served with a correction direction who alleges that the People's Action Party (PAP) government was involved in investment decisions made by sovereign wealth fund company Temasek Holdings in a Facebook post (Channel News Asia 2019a).

${ }^{40}$ Three correction directions were issued against the Singapore Democratic Party (SDP) in relation to two Facebook posts and a website article alleging the retrenchment of Singaporean professionals, managers, and executives (Channel News Asia 2019b).

${ }^{41}$ The States Times Review and the Online Citizen have been issued correction directions for posting or republishing articles critical of Singapore's prison system and alleged arrest of a person (Tang 2020; Kurohi 2020).

${ }^{42}$ See the "Academia SG" website that promotes Singapore studies and archives of commentaries on POFMA (Academia SG 2019).
} 
Anis, Mazwin Nik, and Clarissa Chung. 2018. "PM: Law Regulating Political Funding to Be Proposed." The Star Online, July 9. <https://www.thestar.com.my/news/nation/2018/ 07/09/pm-proposal-for-law-regulating-political-fundingpoliticians-must-declare-assets/>

Anti-Fake News Act. 2018. OIT.org, <http://www.oit.org/dyn/ natlex/docs/ELECTRONIC/106305/130354/F-927153343/ MYS106305\%20Mys.pdf>.

Aronson, Jonathan David, and Peter F. Cowhey. 2017. Digital DNA: Disruption and the Challenges for Global Governance. New York, NY: Oxford University Press.

Aspinall, Edward, Michael W. Davidson, Allen Hicken, and Meredith L. Weiss. 2016. "Local Machines and Vote Brokerage in the Philippines." Contemporary Southeast Asia: A Journal of International and Strategic Affairs 38(2): 191-96.

Aspinall, Edward, Noor Rohman, Ahmad Zainul Hamdi, Rubaidi, and Zusiana Elly Triantini. 2017. "Vote Buying in Indonesia: Candidate Strategies, Market Logic and Effectiveness." Journal of East Asian Studies 17(1): 1-27. $<$ https://doi.org/10.1017/jea.2016.31>.

Baldwin-Philippi, Jessica. 2017. "The Myths of Data-Driven Campaigning." Political Communication 34(4): 627-33. $<$ https://doi.org/10.1080/10584609.2017.1372999>.

Barron, Laignee. 2018. "Could Facebook Have Stopped the Spread of Hate in Myanmar?" Time, April 6. <http://time.com/ 5230474/facebook-myanmar-hate-speech-rohingya/>.

BBC News. 2014. "Arrested for Calling Indonesian City 'Idiotic,"” BBC News, September 5. <https://www.bbc.co.uk/ news/blogs-trending-29035858>.

BBC News. 2019. "Mobs Lynch Eight over Child Abduction Rumours.” BBC News. July 24, sec. Asia. <https://www .bbc.com/news/world-asia-49102074>.

Benkler, Yochai, Robert Faris, and Hal Roberts. 2018. Network Propaganda: Manipulation, Disinformation, and Radicalization in American Politics. New York: Oxford University Press. <http://www.oxfordscholarship.com/view/10.1093/ oso/9780190923624.001.0001/oso-9780190923624>.

Bing, Christopher. 2019. "Exclusive: U.S. Officials Fear Ransomware Attack Against 2020 Election." Reuters, August 27. <https://www.reuters.com/article/us-usa-cyber-electionexclusive-idUSKCN1VG222>.

Birch, Sarah. 2012. Electoral Malpractice. New York: Oxford University Press.

Bounegru, Liliana, Jonathan Gray, Tommaso Venturini, and Michele Mauri. 2017. A Field Guide to "Fake News" and Other Information Disorders. Amsterdam: Public Data Lab and First Draft. <https://www.ssrn.com/abstract= 3097666>.

Bradshaw, Samantha, Lisa-Maria Neudert, and Philip N. Howard. 2018. "Government Responses to Malicious Use of Social Media." Countering the Malicious Use of Social Media. Riga, Latvia: NATO StratCom COE. <https:// www.stratcomcoe.org/government-responses-malicious-usesocial-media>.

Cahn, David, and Jack Cahn. 2018. How to Hack an Election. New York: Sutton Place Press.

Catt, Helena, Andrew Ellis, Michael Maley, Alan Wall, and Peter Wolf. 2014. Electoral Management Design: Revised Edition. Handbook Series. Sweden: International IDEA.
$<$ https://www.idea.int/publications/catalogue/electoralmanagement-design-revised-edition $>$.

Chairill, Tangguh. 2019. "Cybersecurity for Indonesia: What Needs to Be Done?" The Conversation, May 9. <https:// theconversation.com/cybersecurity-for-indonesia-whatneeds-to-be-done-114009>.

Channel News Asia. 2019a. "POFMA Office Directs Brad Bowyer to Correct Facebook Post in First Use of 'Fake News' Law." CNA, November 25. <https://www.channelnewsasia .com/news/singapore/brad-bowyer-facebook-post-falsehoodpofma-fake-news-12122952>.

Channel News Asia. 2019b. "SDP Directed to Correct Facebook Posts and Article Under Online Falsehoods Law." CNA, December 14. <https://www.channelnewsasia.com/ news/singapore/sdp-singapore-democratic-party-fake-newspofma-facebook-12184352>.

Cheeseman, Nic, Gabrielle Lynch, and Justin Willis. 2018. "Digital Dilemmas: The Unintended Consequences of Election Technology." Democratization 25(8): 1397-1418. <https:// doi.org/10.1080/13510347.2018.1470165>.

Chester, Jeff, and Kathryn C. Montgomery. 2017. "The Role of Digital Marketing in Political Campaigns.” Internet Policy Review 6(4). <https://policyreview.info/articles/analysis/ role-digital-marketing-political-campaigns $>$.

Cochrane, Joe. 2017. "Embrace of Atheism Put an Indonesian in Prison." The New York Times, December 20. <https:// www.nytimes.com/2014/05/04/world/asia/indonesian-whoembraced-atheism-landed-in-prison.html>.

Computer Crimes Act. 2007. Ministry of Digital Economy and Society. <http://www.mdes.go.th/assets/portals/1/files/600908_ 01Computer-RelatedCrimeActBE2550Amended-E.pdf $>$.

Daniel, Kaufman, Aart Kraay, and Massimo Mastruzzi. 2010. "The Worldwide Governance Indicators: Methodology and Analytical Issues." World Bank Policy Research Working Paper No. 5430. World Bank Institute. <http://info.worldbank .org/governance/wgi/sc_chart.asp>.

Data Privacy Act. 2012. RA. Vol. 10173. <https://www .privacy.gov.ph/data-privacy-act/>.

Davies, Ed, and Cindy Silviana. 2018. "New Indonesia Web System Blocks More Than 70,000 'Negative' Sites.” Reuters, February 19. <https://www.reuters.com/article/us-indonesiacommunications/new-indonesia-web-system-blocks-morethan-70000-negative-sites-idUSKCN1G30KA>.

Deahl, Dani. 2018. "First Person Convicted Under Malaysia's Fake News Law Gets Month in Jail." The Verge, April 30. <https://www.theverge.com/2018/4/30/17302954/ malaysia-anti-fake-news-act-youtube $>$.

Diamond, Larry. 2010. "Liberation Technology." Journal of Democracy 21(3): 69-83. <https://doi.org/10.1353/ jod.0.0190>.

Dommett, Katharine, and Sam Power. 2019. “The Political Economy of Facebook Advertising: Election Spending, Regulation and Targeting Online." Political Quarterly 90(2): 257-265. <https://doi.org/10.1111/ 1467-923X.12687>.

Economist Intelligence Unit. 2018. "Preparing for Disruption: Technological Readiness Ranking." The Economist. $<$ http://www.eiu.com.libaccess.lib.mcmaster.ca/public/ thankyou_download.aspx?activity=download\&campaignid= TechReadiness $>$. 
Elchahabi, Samer, and Adam Gallagher. 2015. "The Evolving Role of Media in Elections." International Foundation for Electoral Systems, May 21. <http://www.ifes.org/news/ evolving-role-media-elections $>$.

Elections Department Singapore. 2015. Handbook for Parliamentary Election Candidates 2015.

Ellis-Petersen, Hannah. 2019. “'A Real Source of Hope’: Social Media Opens Thailand's Junta to Criticism." The Guardian, March 7, sec. World news. <https://www.theguardian.com/ world/2019/mar/07/a-real-source-of-hope-social-mediaopens-thailands-junta-to-criticism>.

Enli, Gunn Sara, and Eli Skogerbø. 2013. "Personalized Campaigns in Party-Centred Politics." Information, Communication \& Society 16(5): 757-74. <https://doi.org/10.1080/1369118X .2013.782330>.

Etter, Lauren. 2017. "Rodrigo Duterte Turned Facebook into a Weapon, with a Little Help from Facebook." Bloomberg, December 7. <https://www.bloomberg.com/news/features/ 2017-12-07/how-rodrigo-duterte-turned-facebook-into-aweapon-with-a-little-help-from-facebook>.

Faiola, Anthony, and Stephanie Kirchner. 2017. "How Do You Stop Fake News? In Germany, with a Law." Washington Post, April 5, sec. Europe. <https://www.washingtonpost .com/world/europe/how-do-you-stop-fake-news-in-germanywith-a-law/2017/04/05/e6834ad6-1a08-11e7-bcc2-7d1a0973 e7b2_story.html>.

Fair Elections Act. 2018. COMELEC.gov. <http://www.comelec .gov.ph/php-tpls-attachments/2018BSKE/Resolutions/com_ res_10294.pdf>.

Fortin-Rittberger, Jessica. 2014. "The Role of Infrastructural and Coercive State Capacity in Explaining Different Types of Electoral Fraud." Democratization 21(1): 95-117. <https:// doi.org/10.1080/13510347.2012.724064>.

Freedom House. 2018. "Freedom on the Net: Cambodia." November 1. <https://freedomhouse.org/country/cambodia/ freedom-net/2018>.

Freedom House. 2017. "Freedom on the Net: Japan." November 14. <https://freedomhouse.org/country/japan/freedomnet/2017>.

Funke, Daniel, and Daniela Flamini. 2018. "A Guide to AntiMisinformation Actions Around the World." Poynter. May 22, 2018. https://www.poynter.org/news/guide-antimisinformation-actions-around-world.

Goel, Vindu. 2018. "In India, Facebook's WhatsApp Plays Central Role in Elections." Straits Times, May 15. <https:// www.straitstimes.com/asia/south-asia/in-india-facebookswhatsapp-plays-central-role-in-elections $>$.

Goel, Vindu, Hari Kumar, and Sheera Frenkel. 2018. "In Sri Lanka, Facebook Contends with Shutdown After Mob Violence." New York Times, March 8. <https://www .nytimes.com/2018/03/08/technology/sri-lanka-facebookshutdown.html>.

Gomez, Edmund Terence. 2018. "Financing Politics and the 14th General Election." The Star Online, March 5. <https:// www.thestar.com.my/business/business-news/2018/03/05/ financing-politics-and-the-14th-general-election/>.

Gov.sg. 2015. "Are There Limits to How Much a Party Can Spend on Election Campaigns?" Singapore Government, August 31. <http://www.gov.sg/factually/content/are-therelimits-to-how-much-a-party-can-spend-on-election-campaigns $>$.
Hariraksapitak, Pracha, and Aukkarapon Niyomyar. 2018. "Thai Vote Faces Delay After Lawmakers Amend Election Law." Reuters, January 25. <https://www.reuters.com/article/ us-thailand-politics/thai-vote-faces-delay-after-lawmakersamend-election-law-idUSKBN1FE25Y>.

Hern, Alex. 2016. "Philippine Electoral Records Breached in 'Largest Ever' Government Hack." The Guardian, April 11, sec. Technology. <https://www.theguardian.com/ technology/2016/apr/11/philippine-electoral-recordsbreached-government-hack $>$.

Hersh, Eitan D. 2015. Hacking the Electorate: How Campaigns Perceive Voters. New York: Cambridge University Press.

Hoekstra, Ate. 2018. "Cambodia Considers New Law Targeting 'Fake News."” DW.com. April 10. <http://www.dw.com/ en/cambodia-considers-new-law-targeting-fake-news/a43323565>.

HRW. 2019. "Cambodia: Events of 2019." Human Rights Watch, December 16. <https://www.hrw.org/world-report/ 2020/country-chapters/cambodia $>$.

Huang, Hsini, and Tien-Shen Li. 2018. "A Centralised Cybersecurity Strategy for Taiwan.” Journal of Cyber Policy 3(3): 344-62. <https://doi.org/10.1080/23738871.2018.1553987>.

Human Rights Watch. 2018. "Vietnam: Withdraw Problematic Cyber Security Law." Human Rights Watch, June 7. $<$ https://www.hrw.org/news/2018/06/07/vietnam-withdrawproblematic-cyber-security-law $>$.

IDEA. 2016. “Japan.” International IDEA. 2016. <https:// www.idea.int/data-tools/country-view/155/55>.

IDEA. 2019. "Political Finance Database." International IDEA. <https://www.idea.int/data-tools/data/politicalfinance-database $>$

IFES. 2018. "Elections in Indonesia: 2018 Regional Head Elections." International Foundation for Election Systems. $<$ http://www.ifes.org/faqs/elections-indonesia-2018-regionalhead-elections>.

Indonesian Criminal Code (Kitab Undang-Undang Hukum Pidana). 1945. World Intellectual Property Organization. $<$ https://www.wipo.int/edocs/lexdocs/laws/en/id/id039en .pdf $>$.

International Federation of Journalists. 2018. "Bill to Repeal 'Anti-Fake News' Act in Malaysia Fails." IFJ.org, September 13. <https://www.ifj.org/media-centre/news/detail/category/ press-freedom/article/bill-to-repeal-anti-fake-news-act-inmalaysia-fails.html $>$.

Internet World Stats. 2018. "Asia Internet Usage Stats Facebook and 2018 Population Statistics." Internet World Stats, June 30. <https://www.internetworldstats.com/stats3.htm>.

Irawanto, Budi. 2019. "Making It Personal: The Campaign Battle on Social Media in Indonesia's 2019 Presidential Election." Yusof Ishak Institute. <https://www.iseas.edu.sg/ images/pdf/ISEAS_Perspective_2019_28.pdf>.

Jamieson, Kathleen Hall. 2018. Cyberwar: How Russian Hackers and Trolls Helped Elect a President-What We Don't, Can't, and Do Know. New York: Oxford University Press.

Jennings, Ralph. 2019a. "Taiwan Seeks to Rein in Freewheeling Media with Tougher Anti-Fake News Laws." Voice of America, April 22. <https://www.voanews.com/east-asia/ taiwan-seeks-rein-freewheeling-media-tougher-anti-fakenews-laws $>$. 
Jennings, Ralph. 2019b. "Taiwan Raises Suspicion Rival China Is Influencing Elections." Voice of America, July 30. $<$ https://www.voanews.com/east-asia-pacific/taiwan-raisessuspicion-rival-china-influencing-elections $>$.

Johal, Sunil, and Michael Crawford Urban. 2017. Regulating Disruption: Governing in an Era of Rapid Technological Change. Toronto: Mowat Centre. <http://www.deslibris .ca/ID/10090959>.

Kaiser, Shana. 2014. Social Media: A Practical Guide for Electoral Management Bodies. Stockholm: International Institute for Democracy and Electoral Assistance. <https:// www.idea.int/sites/default/files/publications/social-mediaguide-for-electoral-management-bodies.pdf $>$.

Kaufman, Daniel, and Aart Kraay. 2019. "Worldwide Governance Indicators (WGI) Project.” Interactive. Worldwide Governance Indicators. <http://info.worldbank.org/governance/ WGI/\#home>.

Kessler, Glenn. 2016. "Fact-Checking Organizations Around the Globe Embrace Code of Principles." Washington Post, September 15. <https://www.washingtonpost.com/news/ fact-checker/wp/2016/09/15/fact-checking-organizationsaround-the-globe-embrace-code-of-principles/>.

Kovalik, Dan. 2018. The Plot to Control the World: How the US Spent Billions to Change the Outcome of Elections Around the World. New York: Hot Books.

Kurohi, Rei. 2020. "States Times Review's Application to Cancel Pofma Order Rejected; SDP Files Separate Application." Straits Times, January 3. <https://www.straitstimes.com/ singapore/states-times-reviews-application-to-cancel-pofmaorder-rejected-sdp-files-separate $>$.

Lamb, Kate. 2018. "Najib Razak Charged Over Multibillion 1 MDB Corruption Scandal." The Guardian, July 4, sec. World news. <https://www.theguardian.com/world/2018/ jul/04/najib-razak-charged-over-multibillion-dollar-1mdbcorruption-scandal $>$.

Lamb, Kate. 2019. "Indonesia Election Mired in Claims of Foreign Hacking and 'Ghost' Voters." The Guardian, March 19, 2019, sec. World news. <https://www.theguardian.com/ world/2019/mar/19/indonesia-election-mired-in-claims-offoreign-hacking-and-ghost-voters $>$.

Law Concerning Electronic Information and Transactions. 2008. ZAICO.nl. <http://zaico.nl/files/RUU-ITE_english.pdf>.

Law on Election of Members of the National Assembly. 2015. NGO-CEDAW. <http://ngocedaw.org/wp-content/uploads/ 2014/10/tmp_11849-Draft-of-LEMNA-by-CNRP-CPP_ March_08_2015132491924.pdf>.

Lefevre, Amy Sawitta. 2018. "Thai Editor Faces Charges over Picture of Kings Wearing Masks." Reuters, April 1. $<$ https://www.reuters.com/article/us-thailand-insult/thaieditor-faces-charges-over-picture-of-kings-wearing-masksidUSKCN1H80XP>.

Leong, Trinna. 2018a. "Malaysian Politicians Point Fingers as Cambridge Analytica Linked to 2013 Polls." Straits Times, March 20, 2018. <http://www.straitstimes.com/asia/se-asia/ cambridge-analyticas-claim-it-helped-barisan-nasional-in2013-malaysia-election-stirs>.

Leong, Trinna. 2018b. "Malaysians Wary of Fake News Law." Straits Times, March 29. <http://www.straitstimes.com/ asia/se-asia/malaysians-wary-of-fake-news-law $>$.
Lim, Joanne BY. 2017. "Engendering Civil Resistance: Social Media and Mob Tactics in Malaysia." International Journal of Cultural Studies 20(2): 209-27. <https://doi.org/ 10.1177/1367877916683828>.

Lourdes, Marc. 2018. "Malaysia's Anti-Fake News Law Raises Media Censorship Fears." CNN, April 3. <https://www.cnn .com/2018/03/30/asia/malaysia-anti-fake-news-bill-intl/ index.html $>$.

Lovells, Hogan, Julie Brill, Mark Parsons, Hiroto Imai, and Harriet Pearson. 2017. "Changes in Japan Privacy Law to Take Effect in Mid-2017; Key Regulator Provides Compliance Insights." Lexology, February 1. <https://www.lexology.com/ library/detail.aspx?g=efa0a2b0-b73e-456c-b4fa-26a268e $9 \mathrm{e} 751>$

Lum. 2017. "Is Government a Person? Court Rules on AntiHarassment Law Provision.” Text. Straits Times. January 17. $<$ https://www.straitstimes.com/singapore/courts-crime/is-govta-person-court-rules-on-anti-harassment-law-provision $>$.

Marhaenjati, Bayu, and Telly Nathalia. 2019. "Prabowo Spokesman Arrested for Treason and Spreading Fake News." Jakarta Globe, May 20. <https://jakartaglobe.id/context/ prabowo-spokesman-arrested-for-treason-and-spreadingfake-news $>$.

Mazziotta, Matteo, and Adriano Pareto. 2013. "Methods for Constructing Composite Indices: One for All or All for One?" Rivista Italiana Di Economia Demografia e Statistica 2: 14.

McDermid, Charles. 2019. "Facebook: Ban on Foreign Ads Before Thai Poll Not Due to Junta Request." South China Morning Post. January 31. <https://www.scmp.com/news/ asia/southeast-asia/article/2184460/facebook-will-blockforeign-ads-and-bad-actors-thai $>$.

Meredith, Sam. 2018. "Facebook-Cambridge Analytica: A Timeline of the Data Hijacking Scandal." CNBC.com, April 10. <https://www.cnbc.com/2018/04/10/facebookcambridge-analytica-a-timeline-of-the-data-hijackingscandal.html >.

Mie, Ayako. 2013a. "Election Campaigning Takes to Net." Japan Times Online, April 11.<https://www.japantimes.co.jp/news/ 2013/04/11/national/politics-diplomacy/election-campaigningtakes-to-net/>.

Mie, Ayako. 2013b. "Diet OKs Internet Election Campaigns." Japan Times Online, April 19. <https://www.japantimes .co.jp/news/2013/04/19/national/politics-diplomacy/dietoks-internet-election-campaigns/>.

Ministry of Interior. 2019. Civil Servants Election and Recall Act. <https://law.moj.gov.tw/Eng/LawClass/LawAll.aspx? PCode $=$ D0020010 $>$.

Molina, Kristo. 2016. "Indonesian Electronic Information and Transactions Law Amended." White \& Case, December 15. <https://www.whitecase.com/publications/alert/ indonesian-electronic-information-and-transactions-lawamended $>$.

Muzaffar, Chandra. 2018. "Who Is Funding the 14th General Election?" Malaysia Today, March 6. <http://www .malaysia-today.net/2018/03/06/who-is-funding-the-14thgeneral-election/>.

Mydans, Seth. 2011. "In Singapore, Political Campaigning Goes Viral." New York Times, May 5, sec. Asia Pacific. 
$<$ https://www.nytimes.com/2011/05/06/world/asia/06ihtsingapore06.html>.

NEC. 2017. "Amendments to Public Official Election Act Passed." Republic of Korea National Election Commission, February 6. <http://www.nec.go.kr/engvote_2013/04_news/ 02_02.jsp?num=478\&pg=1\&col=\&sw=>.

$\mathrm{Ng}$, Kang-Chung. 2017. "Laptops Containing 3.7 Million Hong Kong Voters' Data Stolen After Chief Executive Election." South China Morning Post, March 28. <https://www.scmp.com/news/hong-kong/politics/article/ 2082566/laptops-containing-37-million-hong-kong-votersdata-stolen>.

O'Connor, Linda. 2015. "10-Step Guide for the Construction of a Composite Indicator.” Text. EU Science Hub-European Commission. January 20. <https://ec.europa.eu/jrc/en/coin/ 10-step-guide/overview $>$.

Oklobdzija, Stan. 2019. "Public Positions, Private Giving: Dark Money and Political Donors in the Digital Age." Research \& Politics 6(1): 2053168019832475. <https://doi.org/ $10.1177 / 2053168019832475>$.

Parliamentary Elections (Election Advertising) Regulations. 2001. Singapore Statutes Online. <https://sso.agc.gov.sg/ SL/PEA1954-RG3>.

Personal Data Protection Act. 2010. International Labour Organization. <http://ilo.org/dyn/natlex/docs/ELECTRONIC/ 89542/102901/F1991107148/MYS89542\%202016.pdf>.

Personal Data Protection Commission Singapore. 2012. Data Protection Act 2012. Personal Data Protection Commission Singapore. <https://www.pdpc.gov.sg/Legislationand-Guidelines/Legislation>.

Personal Data Protection Commission Singapore. 2017. Advisory Guidelines on Application of PDPA to Election Activities. August 8. <https://www.pdpc.gov.sg/Legislation-andGuidelines/Guidelines/Main-Advisory-Guidelines>.

Potkin, Fanny, and Agustinus Beo Da Costa. 2019. "In Indonesia, Facebook and Twitter Are 'Buzzer' Battlegrounds as Elections Loom." Star Online. March 13. <https:// www.thestar.com.my/news/world/2019/03/13/in-indonesiafacebook-and-twitter-are-buzzer-battlegrounds-as-electionsloom $/>$.

Prachatai. 2014. "Liking Anti-Junta Facebook Posts Is a Crime: Thai Police." Prachatai, June 20. <https://prachatai.com/ english/node/4110>.

Price, Monroe E., Stefaan Verhulst, and Libby Morgan, eds. 2013. Routledge Handbook of Media Law. 1st edition. New York: Routledge.

Rabin-Havt, Ari, and Media Matters for America. 2016. Lies, Incorporated: The World of Post-Truth Politics. New York: Anchor.

Rathi, Rahul. 2019. "Effect of Cambridge Analytica's Facebook Ads on the 2016 US Presidential Election." Towards Data Science, January 13. <https://towardsdatascience.com/ effect-of-cambridge-analyticas-facebook-ads-on-the-2016us-presidential-election-dacb5462155d>.

Sani, Mohd Azizuddin Mohd. 2014. "The Social Media Election in Malaysia: The 13th General Election in 2013." Kajian Malaysia 32(2): 123-47.

SEAPA. 2019. "Suppression via Legislation.” Southeast Asian Press Alliance, May 3. <https://pcij.org/article/1628/ cambodia-suppression-via-legislation $>$.
Seiff, Abby. 2018. "Twitter Has a Big Problem in Southeast Asia: Bots Before the Ballot in Malaysia and Beyond." Time, May 4. <http://time.com/5260832/malaysia-electiontwitter-bots-social-media/>.

Senate, Select Committee on Intelligence of the United States. 2018. Disinformation: A Primer in Russian Active Measures and Influence Campaigns Panel I. S. Hrg. 115-40, Pt. 1.

Simpser, Alberto. 2013. Why Governments and Parties Manipulate Elections: Theory, Practice, and Implications. New York: Cambridge University Press.

Singapore Statutes Online. 2019a. Protection from Harassment Act (Amendment) Bill. <https://sso.agc.gov.sg/Bills-Supp/ 11-2019/Published $/ 20190401$ ?DocDate $=20190401>$.

Singapore Statutes Online. 2019b. Protection from Online Falsehoods and Manipulation Act. <https://sso.agc.gov.sg/ActsSupp/18-2019/Published/20190625?DocDate=20190625 >.

Sinpeng, Aim, Angela O'Mahony, and Benjamin Nyblade. 2015. "Social Media Data and the Dynamics of Thai Protests." Asian Journal of Social Science 43(5): 545-66. $<$ https://doi.org/10.1163/15685314-04305003>.

Sone, Pyae. 2018. "Room for Improvement: Myanmar's Campaign Finance Framework." IDEA International, December 11. $<$ https://www.idea.int/news-media/news/room-improvementmyanmar\%E2\%80\%99s-campaign-finance-framework $>$.

Song, Ashley. 2017. "South Korean Lawmaker Proposes AntiFake News Bill." Korea Bizwire (blog), July 27. <http:// koreabizwire.com/south-korean-lawmaker-proposes-antifake-news-bill/89762>.

Stieglitz, Stefan, Tobias Brockmann, and Linh Dang-Xuan. 2012. "Usage of Social Media for Political Communication." PACIS 2012 Proceedings, 22. <http://aisel.aisnet.org/cgi/ viewcontent.cgi?article $=1023 \&$ context $=$ pacis2012>.

Straits Times. 2019. "Concerns over No-Shows, Fake News Ahead of Indonesian Elections." Text. Straits Times. April 3. <https://web.archive.org/web/20190405035114/https:// www.straitstimes.com/asia/se-asia/concerns-over-no-showsfake-news>.

Sukma, Ahmad Novindri. 2019. "Indonesia Needs Transparency in Campaign Funding." Asia Times, March 13. $<$ https://www.asiatimes.com/2019/03/opinion/indonesianeeds-transparency-in-campaign-funding/>.

Sy, Jose Monfred C. 2019. "Duterte and FB Live: Encoding Spectacles and Propaganda." Asian Politics and Policy 11(2): 314-16. <https://doi.org/10.1111/aspp.12447>.

Tang, Louisa. 2020. "Govt Not Required to Prove Statement Is False, AG Argues in TOC's POFMA Appeal Over Death Row Article." TODAYonline, February 6. <https:// www.todayonline.com/singapore/govt-not-required-provestatement-false-ag-argues-tocs-pofma-appeal-over-deathrow-article?cid=emarsys-today_TODAY\%27s\%20morning $\% 20$ briefing \%20for\%20Feb\%207,\%202020\%20\%28 ACTIVE\%29_newsletter_07022020_today>.

Taylor, Adam. 2018. "Cambridge Analytica's Reach Went Far Beyond the U.S. Elections.” Washington Post, March 21. $<$ https://www.washingtonpost.com/news/worldviews/wp/ 2018/03/20/cambridge-analyticas-reach-went-far-beyondthe-u-s-elections/>.

Tenove, Chris, Jordan Buffie, Spencer McKay, and David Moscrop. 2018. "Digital Threats to Democratic Elections: How Foreign Actors Use Digital Techniques to Undermine 
Democracy." Research Report, Centre for the Study of Democratic Institutions, University of British Columbia. SSRN: <https://doi.org/10.2139/ssrn.3235819>.

Tham, Irene. 2019. "Public Service to Roll Out 13 Measures to Protect Citizens' Personal Data Following Data Breaches." Straits Times, July 15. <https://www.straitstimes.com/ singapore/high-level-panel-rolls-out-13-cyber-securitymeasures-for-the-public-service-following $>$.

Tisnadibrata, Ismira Lutfia. 2018. "Indonesia Introduces New Internet Censorship System.” Arab News, January 2. $<$ http://www.arabnews.com/node/1218011/world $>$.

Today Online. 2018. "Muslim Cyber Army: A 'Fake News' Operation Designed to Derail Indonesia's Leader." TODAYonline, March 18. <http://www.todayonline.com/ world/muslim-cyber-army-fake-news-operation-designedderail-indonesias-leader?cid=emarsys-today_TODAY\%27s $\% 20$ morning $\% 20$ briefing $\% 20$ for $\% 20$ March $\% 2019, \% 20$ 2018\%20\%28ACTIVE\%29_newsletter_19032018_today >.

Tonsakulrungruang. 2019. "Thailand's Tainted Election Commission." New Mandala (blog), April 17. <https://www .newmandala.org/thailands-tainted-election-commission/>.

The Jakarta Post. 2014. "Atheist Alexander Aan Gets of Prison." The Jakarta Post, January 31. <http://www .thejakartapost.com/news/2014/01/31/atheist-alexander-aangets-prison.html.>

Tsuruoka, Doug. 2018. "Asia Ahead of US in Passing Laws Against Social Media Abuse." Asia Times, March 1. $<$ http://www.atimes.com/article/asia-ahead-us-passing-lawssocial-media-abuse/>.

Tun, Aung. 2015. "Time to Reform Campaign Financing." The Myanmar Times, October 7. <https://www.mmtimes.com/ opinion/16871-time-to-reform-campaign-financing.html $>$.

Ufen, Andreas. 2015. "Laissez-Faire Versus Strict Control of Political Finance: Hegemonic Parties and Developmental States in Malaysia and Singapore." Critical Asian Studies 47(4): 564-86. <https://doi.org/10.1080/14672715.2015 $.1082263>$.

Umeda, Sayuri. 2016. "Regulation of Campaign Finance and Free Advertising: Japan.” Law Library of Congress. <https:// www.loc.gov/law/help/campaign-finance-regulation/japan .php\#Spending $>$.

Waitoolkiat, Napisa, and Paul Chambers. 2015. "Political Party Finance in Thailand Today: Evolution, Reform, and Control." Critical Asian Studies 47 (4): 611-40. <https://doi .org/10.1080/14672715.2015.1091211>.
Walker, Christopher, and Jessica Ludwig. 2017. "The Meaning of Sharp Power." Foreign Affairs, November 16. <https:// www.foreignaffairs.com/articles/china/2017-11-16/meaningsharp-power>.

Wardle, Claire. 2017. "Fake News. It's Complicated." First Draft News. February 16. <https://firstdraftnews.org:443/ fake-news-complicated/>.

Yangyue, Liu. 2014a. "Transgressiveness, Civil Society and Internet Control in Southeast Asia." Pacific Review 27(3): 383-407. <https://doi.org/10.1080/09512748.2014.909520>.

Yangyue, Liu. 2014b. "Controlling Cyberspace in Malaysia: Motivations and Constraints." Asian Survey 54(4): 80123. <https://doi.org/10.1525/as.2014.54.4.801>.

Yeh, Sophia, and Jamie Wang. 2013. "Over 350 Cases Fined for Excess Political Donations.” Focus Taiwan, June 12. $<$ http://focustaiwan.tw/news/aipl/201306120032.aspx>.

Yim, Hyunsu. 2018. "South Korea Battles Fake News." Korea Bizwire (blog), April 10. <http://koreabizwire.com/southkorea-battles-fake-news/116592>.

Zhang, Laney. 2019. "Taiwan: New Cybersecurity Law Takes Effect." Global Legal Monitor, January 30. <http:// www.loc.gov/law/foreign-news/article/taiwan-newcybersecurity-law-takes-effect/>.

Zuiderveen Borgesius, Frederik J., Judith Moller, Sanne Kruikemeier, Ronan Ó Fathaigh, Kristina Irion, Tom Dobber, Balazs Bodo, and Claes de Vreese. 2018. "Online Political Microtargeting: Promises and Threats for Democracy." Utrecht Law Review 14(1): 82-96.

Address correspondence to: Netina Tan

Department of Political Science McMaster University Kenneth Taylor Hall, Room 541 1280 Main Street West Hamilton, ON L8S 4M4 Canada

E-mail: netina@mcmaster.ca

Received for publication September 26, 2019; accepted November 22, 2019; published online April 29, 2020. 


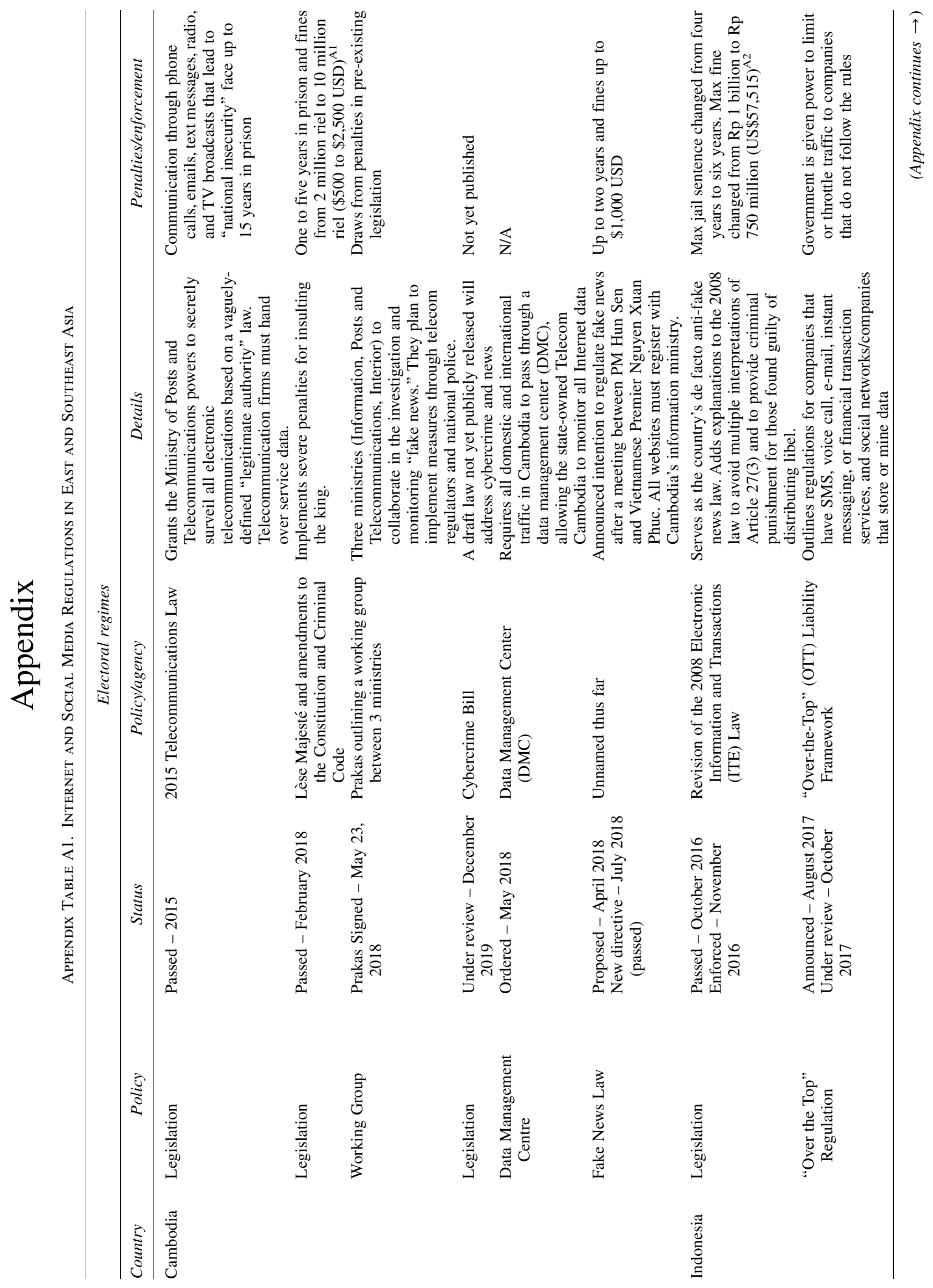




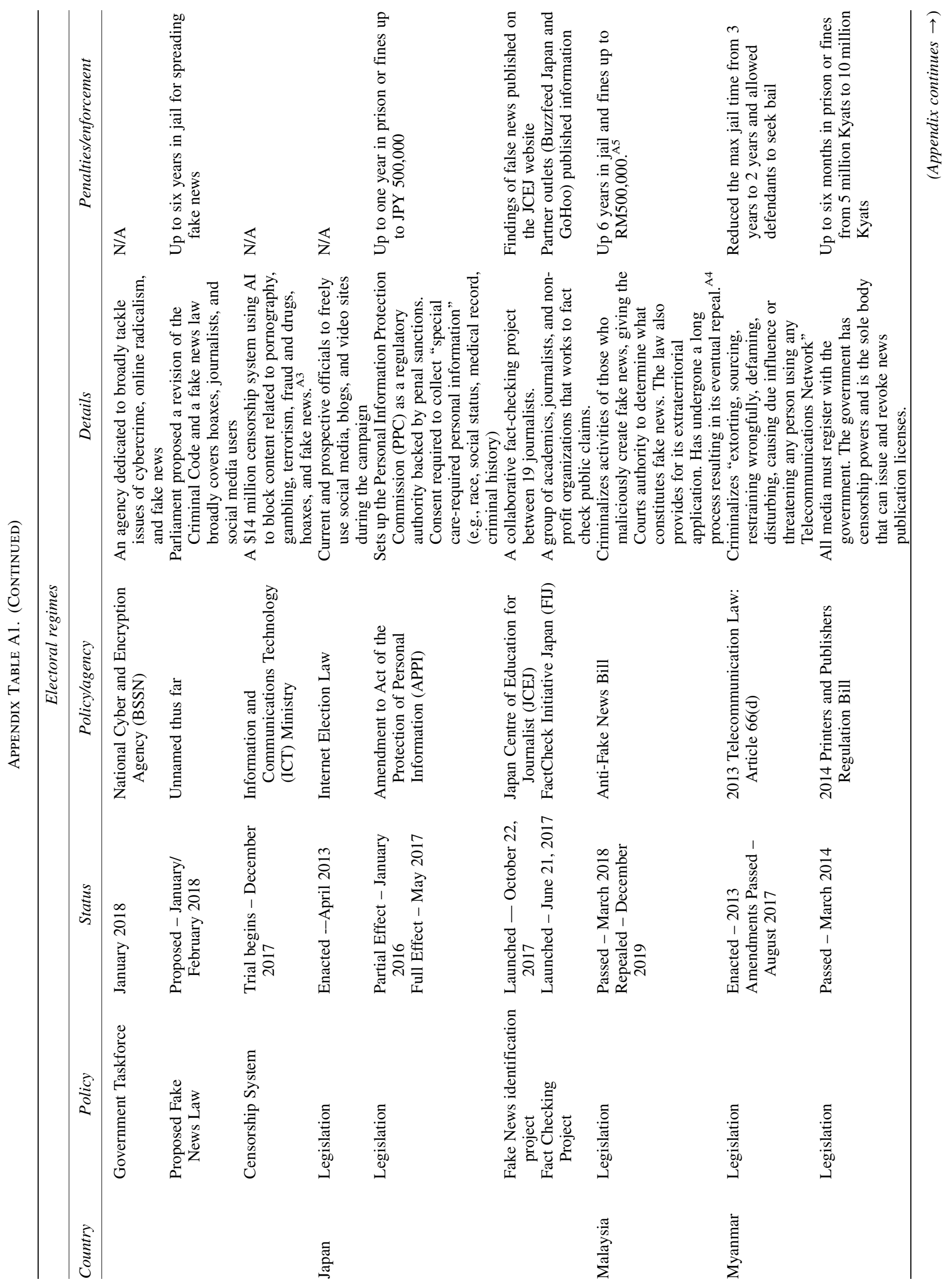




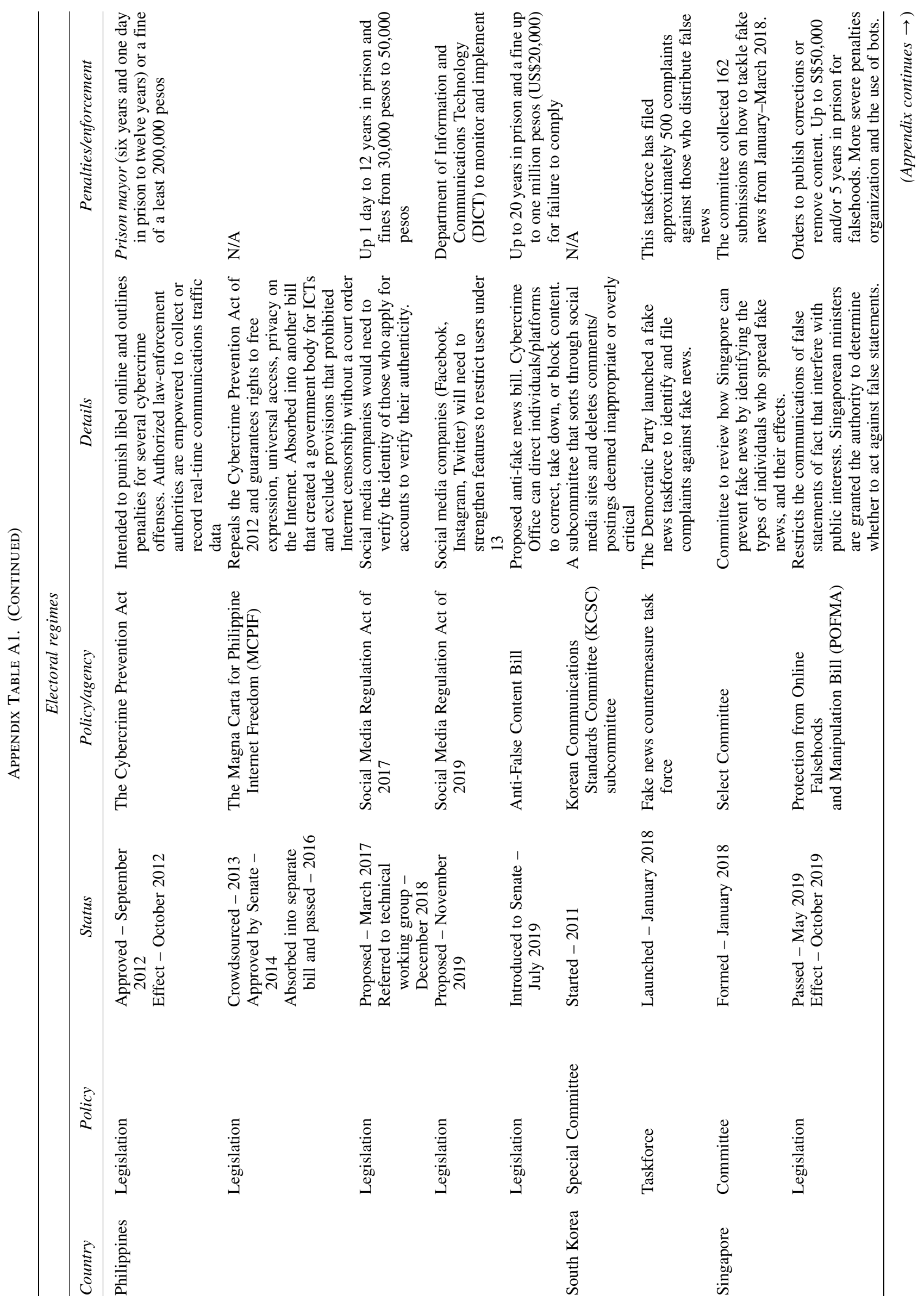




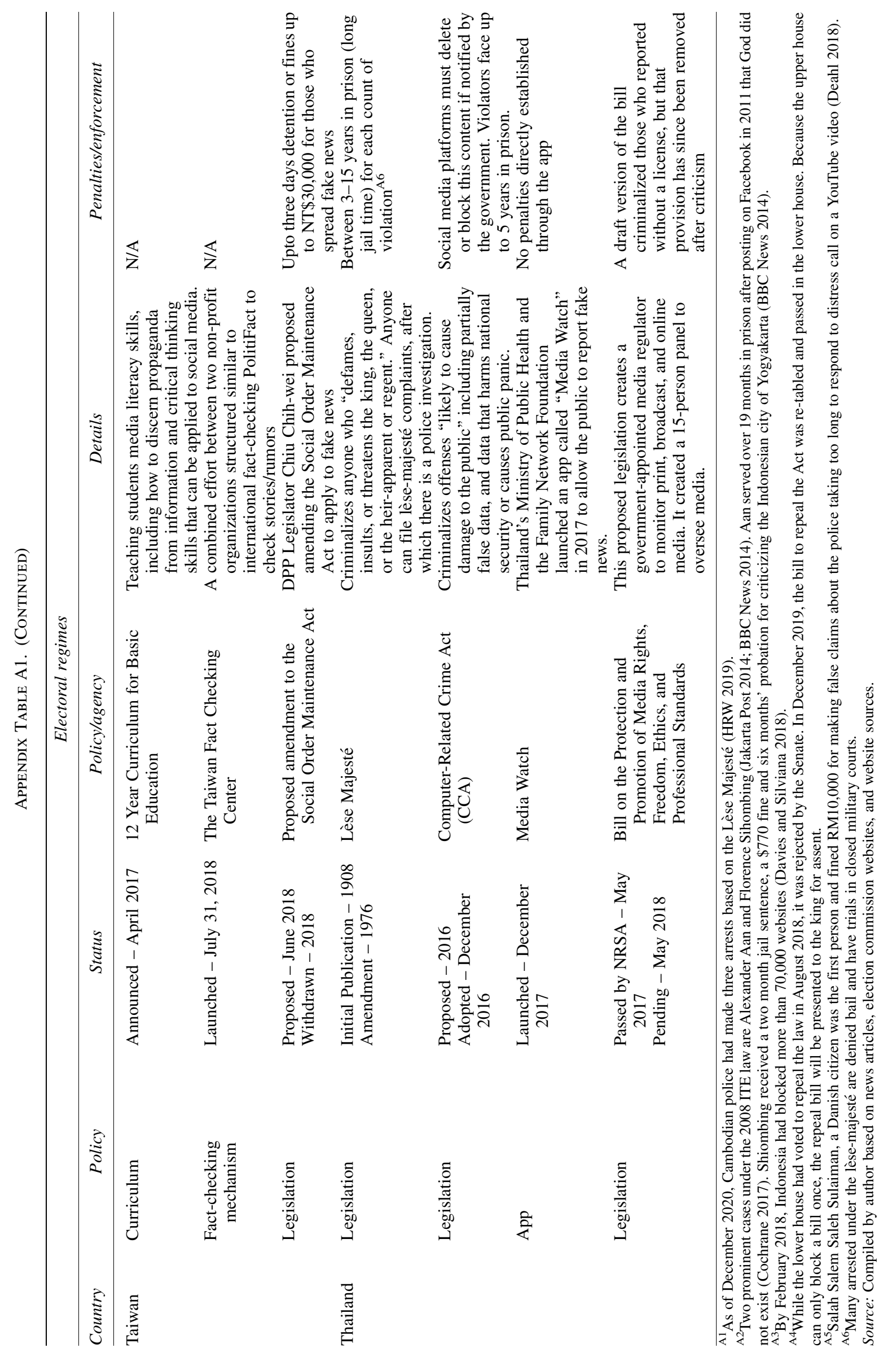


Appendix Table B1. Online Electoral Campaign and Political Donations in East and Southeast Asia

\begin{tabular}{|c|c|c|c|c|c|c|c|}
\hline & $\begin{array}{c}\text { Does the country } \\
\text { publish the lists } \\
\text { of parties } \\
\text { and/or candidates } \\
\text { registered for } \\
\text { elections online? }\end{array}$ & $\begin{array}{l}\text { Are there } \\
\text { provisions for } \\
\text { free or subsidized } \\
\text { access to media } \\
\text { for political } \\
\text { parties? }\end{array}$ & $\begin{array}{l}\text { If there are provisions } \\
\text { for political parties } \\
\text { to access free or } \\
\text { subsidized media, } \\
\text { what criteria } \\
\text { determine } \\
\text { access allocation? }\end{array}$ & $\begin{array}{l}\text { Are there } \\
\text { provisions } \\
\text { for free or } \\
\text { subsidized } \\
\text { access to } \\
\text { media for } \\
\text { candidates? }\end{array}$ & $\begin{array}{l}\text { Regulations } \\
\text { on online } \\
\text { campaigning? }\end{array}$ & $\begin{array}{c}\text { Restrictions } \\
\text { on campaign } \\
\text { spending? }\end{array}$ & $\begin{array}{c}\text { Restrictions } \\
\text { on political } \\
\text { donations? }\end{array}$ \\
\hline Cambodia & Yes & $\begin{array}{l}\text { Yes, provisions } \\
\text { unclear }\end{array}$ & $\begin{array}{l}\text { Equal, provisions } \\
\text { unclear }\end{array}$ & No & $\mathrm{No}^{\mathrm{B} 1}$ & No & $\mathrm{No}^{\mathrm{B} 2}$ \\
\hline Indonesia & Yes & Yes $^{\mathrm{B} 3}$ & $\mathrm{~N} / \mathrm{A}$ & No & No & $\mathrm{Yes}^{\mathrm{B} 4}$ & $\mathrm{Yes}^{\mathrm{B} 5}$ \\
\hline Japan & No & Yes & $\begin{array}{c}\text { Equal, if at least } \\
12 \text { candidates }\end{array}$ & $\begin{array}{l}\text { Yes, some } \\
\quad \text { elections }\end{array}$ & Yes $^{\text {B6 }}$ & $\mathrm{Yes}^{\mathrm{B} 7}$ & $\mathrm{Yes}^{\mathrm{B} 8}$ \\
\hline Malaysia & Yes & N/A & N/A & N/A & No & Yes $^{\mathrm{B} 9}$ & $\mathrm{No}^{\mathrm{B} 10}$ \\
\hline Myanmar & Yes & Yes & $\begin{array}{l}\text { Equal, free equal } \\
\text { airtime }\end{array}$ & No & No & Yes $^{\mathrm{B} 11}$ & $\mathrm{No}^{\mathrm{B} 12}$ \\
\hline Philippines & Yes & Yes, with limits ${ }^{\mathrm{B} 13}$ & N/A & Yes & Yes & Yes $^{\mathrm{B} 14}$ & $\mathrm{No}^{\mathrm{B} 15}$ \\
\hline Singapore & Yes & No & N/A & No & Yes & Yes $^{\mathrm{B} 16}$ & Yes $^{\mathrm{B} 17}$ \\
\hline S. Korea & Yes & Yes & Share of seats & Yes & Yes & Yes & $\mathrm{Yes}^{\mathrm{B} 18}$ \\
\hline Taiwan & Yes & Yes $^{\text {B19 }}$ & Equal $^{\text {B20 }}$ & $\mathrm{Yes}^{\mathrm{B} 21}$ & No & Yes & $\mathrm{Yes}^{\mathrm{B} 22}$ \\
\hline Thailand & No & Yes & Share of seats & No & $\mathrm{Yes}^{\mathrm{B} 23}$ & $\mathrm{Yes}^{\mathrm{B} 24}$ & No \\
\hline
\end{tabular}

$\overline{{ }^{B 1} \text { Articles } 305 \text { and } 307 \text { of the Criminal Code of the Kingdom of Cambodia, which govern defamation, are frequently used to restrict online speech. }}$

${ }^{\mathrm{B} 2}$ No restrictions on individual and corporate donations or anonymous political donations. The Political Parties Law and Law on the Election of the Members of the National Assembly bans donations from foreign interests and from trade unions to parties.

${ }^{\mathrm{B} 3}$ Parties contesting granted equal access to public television and public radio.

${ }^{\mathrm{B} 4}$ The Law on the Government Procedures and Regulations on the Elections of the Governor, Regent, and Candidates grants the General Election Commission (KPU) authority to restrict campaign finances based on voters, coverage, and region. Campaign expenditure caps have been criticized as very high.

${ }^{\mathrm{B} 5}$ The Political Parties Law and General Election Law ban foreign and anonymous donations. The laws outline donation limits for individuals and

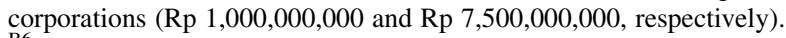

${ }^{\mathrm{B} 6}$ The 2013 Public Offices Election Law (POEL) lifted a previous ban on internet campaigning. Limits remain on paid online advertising and campaign emails, which could only be sent directly by a party or candidate — not a supporter —in a measure designed to prevent fraud (Freedom House 2017).

${ }^{\mathrm{B} 7}$ Spending limits are determined by the type of election. House of Councillor candidates elected through PR have a maximum spending limit of $¥ 52$ million. House of Councillors and House of Representative candidates have spending limits calculated based on the number of district voters and elected members (Umeda 2016).

${ }^{\mathrm{B} 8}$ The Political Funds Control Act bans foreign and corporate donations, restricts anonymous donations to parties to within $¥ 1,000$. It sets limits for individual ( $¥ 20$ million per year) and corporate donations ( $¥ 7.5$ million to $¥ 30$ ).

${ }^{\text {B9 }}$ The Election Offenses Act 1954 limits spending to RM200,000 for parliamentary seats and RM100,000 for state seats.

${ }^{\mathrm{B} 10}$ Parties must disclose their funding under the Societies Act but not their funding source.

${ }^{\text {B11 }}$ Candidates have spending limits in 2015, to spend more than K10 million (Tun 2015).

${ }^{B 12}$ The Political Parties Registration Law and Hluttaws Election Law ban foreign and anonymous donations, but place no limits for individuals or corporations.

${ }^{\mathrm{B} 13} \mathrm{EMB}$ ensures all parties access media on same terms. Free access not assured.

${ }^{\mathrm{B} 14}$ Restrictions on candidate and party spending. Resolution No. 9991, Rule 1 outlines. Spending limits based on the number of voters registered in the constituency and the position.

${ }^{\mathrm{B} 15}$ There are no limits on the amount individuals or companies can donate in the Philippines.

${ }^{B} 16$ Campaign spending limit for candidates based on registered voters (S\$4.00 per voter) (Gov.sg 2015).

${ }^{\mathrm{B}}{ }^{17}$ According to the Political Donations Act, political associations, candidates, and donors who contribute in aggregate more than $\$ 10,000$ must file donation reports periodically with the Registrar of Political Donations. There are, however, no limits on the amount an individual or company can contribute.

${ }^{\text {B } 18}$ The 1965 Political Fund Act requires donors who contribute more than USD 1,200 to disclose their identity by donating through cheque, credit card, account transfer, or other traceable means. All corporations are banned from contributing to political campaigns after 2005.

${ }^{\mathrm{B} 19}$ Candidates to present political views on national television for no shorter than one hour.

${ }^{\mathrm{B} 20}$ Equal for central public officials, provincial governors, and municipal mayoral elections.

${ }^{\mathrm{B} 21}$ Candidates have access to national TV channels (but no advertisement on radio/TV).

${ }^{\mathrm{B} 22}$ Individual candidates can donate up to NT $\$ 100,000$ while corporations can donate up to NT\$1 million annually per candidate. Individuals are limited to NT\$200,000 and corporations NT\$2 million for total political contributions in a year (Yeh and Wang 2013).

${ }^{\mathrm{B} 23}$ The junta's ban on political campaigning has yet to be lifted, although it issued an order in December of 2017 that allows parties to conduct some preparation ahead of the poll (Hariraksapitak and Niyomyar 2018).

${ }^{\mathrm{B} 24}$ Spending limits which have varied from election to election- $\$ 30,893$ per candidate in 2001 and \$46,339 per candidate in 2005 and 2011 (Waitoolkiat and Chambers 2015, 624).

Source: Compiled by author based on sources from IDEA database and news articles. 